\title{
Nitrogen cycling in shallow low-oxygen coastal waters off Peru from nitrite and nitrate nitrogen and oxygen isotopes
}

\author{
Happy Hu ${ }^{1, *}$, Annie Bourbonnais ${ }^{1, *}$, Jennifer Larkum ${ }^{1}$, Hermann W. Bange ${ }^{2}$, and Mark A. Altabet ${ }^{1}$ \\ ${ }^{1}$ School for Marine Science and Technology, University of Massachusetts Dartmouth, 706 South Rodney French Blvd, \\ New Bedford, MA 02744-1221, USA \\ ${ }^{2}$ GEOMAR Helmholtz Centre for Ocean Research Kiel, Düsternbrooker Weg 20, 24105 Kiel, Germany \\ *These authors contributed equally to this work.
}

Correspondence to: Annie Bourbonnais (abourbonnais@umassd.edu)

Received: 17 April 2015 - Published in Biogeosciences Discuss.: 18 May 2015

Revised: 14 January 2016 - Accepted: 7 February 2016 - Published: 9 March 2016

\begin{abstract}
O}_{2}$ deficient zones (ODZs) of the world's oceans are important locations for microbial dissimilatory nitrate $\left(\mathrm{NO}_{3}^{-}\right)$reduction and subsequent loss of combined nitrogen (N) to biogenic $\mathrm{N}_{2}$ gas. ODZs are generally coupled to regions of high productivity leading to high rates of $\mathrm{N}$-loss as found in the coastal upwelling region off Peru. Stable N and $\mathrm{O}$ isotope ratios can be used as natural tracers of ODZ Ncycling because of distinct kinetic isotope effects associated with microbially mediated $\mathrm{N}$-cycle transformations. Here we present $\mathrm{NO}_{3}^{-}$and nitrite $\left(\mathrm{NO}_{2}^{-}\right)$stable isotope data from the nearshore upwelling region off Callao, Peru. Subsurface oxygen was generally depleted below about $30 \mathrm{~m}$ depth with concentrations less than $10 \mu \mathrm{M}$, while $\mathrm{NO}_{2}^{-}$concentrations were high, ranging from 6 to $10 \mu \mathrm{M}$, and $\mathrm{NO}_{3}^{-}$was in places strongly depleted to near $0 \mu \mathrm{M}$. We observed for the first time a positive linear relationship between $\mathrm{NO}_{2}^{-} \delta^{15} \mathrm{~N}$ and $\delta^{18} \mathrm{O}$ at our coastal stations, analogous to that of $\mathrm{NO}_{3}^{-} \mathrm{N}$ and $\mathrm{O}$ isotopes during $\mathrm{NO}_{3}^{-}$uptake and dissimilatory reduction. This relationship is likely the result of rapid $\mathrm{NO}_{2}^{-}$turnover due to higher organic matter flux in these coastal upwelling waters. No such relationship was observed at offshore stations where slower turnover of $\mathrm{NO}_{2}^{-}$facilitates dominance of isotope exchange with water. We also evaluate the overall isotope fractionation effect for N-loss in this system using several approaches that vary in their underlying assumptions. While there are differences in apparent fractionation factor ( $\varepsilon$ ) for $\mathrm{N}$-loss as calculated from the $\delta^{15} \mathrm{~N}$ of $\mathrm{NO}_{3}^{-}$, dissolved inorganic $\mathrm{N}$, or biogenic $\mathrm{N}_{2}$, values for $\varepsilon$ are generally much lower than previously reported, reaching as low as $6.5 \%$. A possible explanation is the influence of sedimentary $\mathrm{N}-$ loss at
\end{abstract}

our inshore stations which incurs highly suppressed isotope fractionation.

\section{Introduction}

Chemically combined nitrogen $(\mathrm{N})$, e.g., nitrate $\left(\mathrm{NO}_{3}^{-}\right)$, is an important phytoplankton nutrient limiting primary productivity and carbon export throughout much of the ocean (e.g. Gruber, 2008). The marine nitrogen cycle involves a series of microbial processes, which transfer $\mathrm{N}$ between a number of chemical forms. These include $\mathrm{N}_{2}$ fixation, nitrification (ammonium $\left(\mathrm{NH}_{4}^{+}\right)$and nitrite $\left(\mathrm{NO}_{2}^{-}\right)$oxidation), and loss of combined $\mathrm{N}$ to $\mathrm{N}_{2}$ via denitrification and anaerobic ammonium oxidation (anammox). Of particular importance is the global balance between sources of combined $\mathrm{N}\left(\mathrm{N}_{2}\right.$ fixation) and $\mathrm{N}$-loss processes which ultimately control the combined $\mathrm{N}$ content of the ocean and thus its productivity and strength of the biological carbon pump. N-loss typically occurs under nearly anoxic conditions where the first step, dissimilatory $\mathrm{NO}_{3}^{-}$reduction to $\mathrm{NO}_{2}^{-}$, active at oxygen $\left(\mathrm{O}_{2}\right)$ concentrations less than $\sim 25 \mu \mathrm{M}$ (Kalvelage et al., 2011), is used by heterotrophic microbes in lieu of $\mathrm{O}_{2}$ for respiration. Canonically, the denitrification pathway of successive reduction of $\mathrm{NO}_{3}^{-}, \mathrm{NO}_{2}^{-}$, nitric oxide (NO), and nitrous oxide $\left(\mathrm{N}_{2} \mathrm{O}\right)$ to $\mathrm{N}_{2}$ was considered as the dominant pathway for $\mathrm{N}$-loss. However, since the early 2000s, anammox $\left(\mathrm{NO}_{2}^{-}\right.$ $+\mathrm{NH}_{4}^{+} \rightarrow \mathrm{N}_{2}$ ) was found to be widespread in the ocean (Kuypers et al., 2003, 2005; Hamersley et al., 2007; Dalsgaard et al., 2012; Kalvelage et al., 2013). While it is still a 
matter of debate whether denitrification or anammox is the dominant pathways for $\mathrm{N}$-loss in Oxygen Minimum Zones (ODZs) (e.g., Lam et al., 2009; Ward et al., 2009), both Nloss processes have been shown to strongly vary spatially and temporally and are linked to organic matter export and composition (Kalvelage et al., 2013; Babbin et al., 2014). It follows that there is still considerable uncertainty as to the controls on N-loss as well as the role for other linking processes such as DNRA $\left(\mathrm{NO}_{3}^{-}\right.$to $\left.\mathrm{NH}_{4}^{+}\right)$and $\mathrm{NO}_{2}^{-}$oxidation in the absence of $\mathrm{O}_{2}$.

Marine $\mathrm{N}$-loss to $\mathrm{N}_{2}$ occurs predominately in reducing sediments and the $\mathrm{O}_{2}$ deficient water columns found in the Arabian Sea and Eastern Tropical North and South Pacific ODZs (Lam and Kuypers, 2011 and references therein; U1loa et al., 2012). $\mathrm{NO}_{2}^{-}$is an important intermediate during $\mathrm{N}$-loss and generally accumulates at concentrations up to $\sim 10 \mu \mathrm{M}$ in these regions (Codispoti et al., 1986; Casciotti et al., 2013). The depletion of $\mathrm{NO}_{3}^{-}$is typically quantified as a dissolved inorganic $\mathrm{N}\left(\mathrm{DIN}=\mathrm{NO}_{3}^{-}+\mathrm{NO}_{2}^{-}+\mathrm{NH}_{4}^{+}\right)$deficit relative to phosphate $\left(\mathrm{PO}_{4}^{-3}\right)$ assuming Redfield stoichiometry and the accumulation of biogenic $\mathrm{N}_{2}$ (when measured) is detected as anomalies in $\mathrm{N}_{2}$ / Ar relative to saturation with atmosphere (Richards and Benson, 1961; Chang et al., 2010; Bourbonnais et al., 2015).

$\mathrm{NO}_{3}^{-}$and $\mathrm{NO}_{2}^{-} \mathrm{N}$ and $\mathrm{O}$ isotopes represent a useful tool to study $\mathrm{N}$ cycle transformations as they respond to in situ processes and integrate over their characteristic time and space scales. Biologically mediated reactions are generally faster for lighter isotopes. For instance, both $\mathrm{NO}_{3}^{-}$uptake and dissimilatory $\mathrm{NO}_{3}^{-}$ reduction produce a strong enrichment in both ${ }^{15} \mathrm{~N}$ $\left(\delta^{15} \mathrm{~N}=\left[\left({ }^{15} \mathrm{~N} /{ }^{14} \mathrm{~N}_{\text {sample }}\right) /\left({ }^{15} \mathrm{~N} /{ }^{14} \mathrm{~N}_{\text {standard }}\right)-1\right] \times 1000\right)$ and ${ }^{18} \mathrm{O} \quad\left(\delta^{18} \mathrm{O}=\left[\left({ }^{18} \mathrm{O} /{ }^{16} \mathrm{O}_{\text {sample }}\right) /\left({ }^{18} \mathrm{O} /{ }^{16} \mathrm{O}_{\text {standard }}\right)-\right.\right.$ $1] \times 1000)$ in the residual $\mathrm{NO}_{3}^{-}$(Cline and Kaplan, 1975; Brandes et al., 1998; Voss et al., 2001; Granger et al., 2004, 2008; Sigman et al., 2005).

Canonical values for the $\mathrm{N}$ isotope effect $(\varepsilon \approx$ $\delta^{15} \mathrm{~N}_{\text {substrate }}-\delta^{15} \mathrm{~N}_{\text {product }}$, without significant substrate depletion) associated with microbial $\mathrm{NO}_{3}^{-}$reduction during water column denitrification range from 20 to $30 \%$ (Brandes et al., 1998; Voss et al., 2001; Granger et al., 2008). In contrast, the expression of the isotope effect of sedimentary denitrification is highly suppressed as compared to the water-column (generally $<3 \%$ ) mostly due to near complete consumption of the porewater $\mathrm{NO}_{3}^{-}$and diffusion limitation (Brandes and Devol, 1997; Lehmann et al., 2007; Alkhatib et al., 2012). The $\delta^{15} \mathrm{~N}$ and $\delta^{18} \mathrm{O}$ of $\mathrm{NO}_{3}^{-}$are affected in fundamentally different ways during $\mathrm{NO}_{3}^{-}$consumption and production processes. The ratio of the ${ }^{15} \mathrm{~N}$ and ${ }^{18} \mathrm{O}$ fractionation factors $\left({ }^{18} \varepsilon:{ }^{15} \varepsilon\right)$ during $\mathrm{NO}_{3}^{-}$consumption during denitrification or assimilation by phytoplankton in surface waters is close to $1: 1$ (Casciotti et al., 2002; Granger et al., 2004, 2008). While the $\delta^{15} \mathrm{~N}$ of the newly nitrified $\mathrm{NO}_{3}^{-}$depends on the $\delta^{15} \mathrm{~N}$ of the precursor molecule being nitrified, the $\mathrm{O}$ atom is mostly derived from water (with a $\delta^{18} \mathrm{O}$ of $\sim 0 \%$ ) with significant isotopic fractionation associated with $\mathrm{O}$ incorporation during $\mathrm{NO}_{2}^{-}$and $\mathrm{NH}_{4}^{+}$oxidation (Casciotti, 2002; Buchwald and Casciotti, 2010; Casciotti et al., 2010). Therefore, any deviation from this $1: 1$ ratio in the field has been interpreted as evidence that $\mathrm{NO}_{3}^{-}$regeneration is co-occurring with $\mathrm{NO}_{3}^{-}$consumption (Sigman et al., 2005; Casciotti and McIlvin, 2007; Bourbonnais et al., 2009). $\mathrm{NO}_{2}^{-}$oxidation is associated with an inverse $\mathrm{N}$ isotope effect (Casciotti, 2009), atypical of biogeochemical reactions, and can cause both lower and higher ratios for ${ }^{18} \varepsilon:{ }^{15} \varepsilon$ compared to pure $\mathrm{NO}_{3}^{-}$assimilation or denitrification, depending on the initial isotopic compositions of the $\mathrm{NO}_{2}^{-}$and $\mathrm{NO}_{3}^{-}$and the ${ }^{18} \mathrm{O}$ added back (Casciotti et al., 2013).

Additional information on N-cycling processes can be obtained from the isotopic composition of $\mathrm{NO}_{2}^{-}$. For example, because of its inverse $\mathrm{N}$ isotope effect, $\mathrm{NO}_{2}^{-}$oxidation results in a lower $\mathrm{NO}_{2}^{-} \delta^{15} \mathrm{~N}$ than initially produced by $\mathrm{NH}_{4}^{+}$oxidation and $\mathrm{NO}_{3}^{-}$reduction (Casciotti, 2009; Brunner et al., 2013). Logically, $\mathrm{NO}_{2}^{-}$reduction would be expected to produce a positive relationship between $\delta^{15} \mathrm{~N}-\mathrm{NO}_{2}^{-}$and $\delta^{18} \mathrm{O}-$ $\mathrm{NO}_{2}^{-}$though there are no quantitative observations in the literature. Analogous to $\mathrm{NO}_{3}^{-}$reduction, it also involves enzymatic breakage of the N-O bond. However, O-isotope exchange of $\mathrm{NO}_{2}^{-}$with water (as a function of $\mathrm{pH}$ and temperature) would reduce the slope of a $\mathrm{NO}_{2}^{-} \delta^{18} \mathrm{O}$ vs. $\delta^{15} \mathrm{~N}$ relationship toward zero. $\mathrm{NO}_{2}^{-}$turnover time can therefore be assessed from this observed relationship and in situ $\mathrm{pH}$ and temperature (Buchwald and Casciotti, 2013).

It is still under discussion whether the global ocean $\mathrm{N}$ budget is in balance. Current estimates from direct observations and models for $\mathrm{N}_{2}$ fixation, considered the primary marine $\mathrm{N}$ source, range from 110-330 $\mathrm{Tg} \mathrm{N} \mathrm{yr}^{-1}$ (Brandes and Devol, 2002; Gruber, 2004; Deutsch et al., 2007; Eugster and Gruber, 2012; Großkopf et al., 2012). Estimates for major marine $\mathrm{N}$-sinks, i.e., denitrification and anammox in the watercolumn of oxygen deficient zones and sediments account for 145-450 Tg N yr ${ }^{-1}$ (Gruber, 2004; Codispoti, 2007; DeVries et al., 2012; Eugster and Gruber, 2012). Large uncertainties are associated with this budget, mainly in constraining the proportion of sedimentary denitrification which is typically estimated from ocean's $\mathrm{N}$ isotope balance and the expressed isotope effects for water-column vs. sedimentary $\mathrm{NO}_{3}^{-}$reduction during denitrification (e.g. Brandes and Devol, 2002; Altabet, 2007; DeVries et al., 2012). Liu (1979) was first to suggest a lower $\varepsilon$ for denitrification in the Peru ODZ as compared to the subsequently accepted canonical range for $\mathrm{NO}_{3}^{-}$ reduction of 20 to $30 \%$ (Brandes et al., 1998; Voss et al., 2001; Granger et al., 2008). Ryabenko et al. (2012) provided a more widely distributed set of data in support. Most recently, a detailed study in a region of extreme N-loss associated with a Peru coastal mode-water eddy confirmed an $\varepsilon$ value for $\mathrm{N}$-loss of $\sim 14 \%$ (Bourbonnais et al., 2015). Ap- 
plying such a lowered value to global budgets would bring the global $\mathrm{N}$ budget closer to balance.

Ryabenko et al. (2012) also suggested that $\varepsilon$ values were even lower in the shelf region of the Peru ODZ. To investigate further, we present here $\mathrm{N}$ and $\mathrm{O}$ isotope data for $\mathrm{NO}_{2}^{-}$ and $\mathrm{NO}_{3}^{-}$from shallow coastal waters near Callao, off the coast of Peru. These waters are highly productive as a consequence of active upwelling that is also responsible for shoaling of the oxycline. We determine the relationship between $\mathrm{NO}_{2}^{-} \delta^{15} \mathrm{~N}$ and $\delta^{18} \mathrm{O}$ and its implication for $\mathrm{NO}_{2}^{-}$cycling in these shallow waters as compared to offshore stations. We finally derive isotope effects for $\mathrm{N}$-loss and infer the likely influence of sedimentary N-loss, which incurs a highly suppressed isotope effect, at our relatively shallow sites.

\section{Material and methods}

\subsection{Sampling}

The R/V Meteor 91 research cruise (M91) to the eastern tropical South Pacific Ocean off Peru in December 2012 was part of the SOPRAN program and the German SFB 754 project. It included an along shore transect of seven inner shelf stations located between 12 to $14^{\circ} \mathrm{S}$ that were chosen for this study (Fig. 1). These stations had a maximum depth of $150 \mathrm{~m} \mathrm{ex}$ cept for station 68 ( $250 \mathrm{~m}$ depth). We additionally sampled deep offshore stations during the M90 cruise in November 2012. Samples for $\mathrm{NO}_{3}^{-}$and $\mathrm{NO}_{2}^{-}$isotopic composition and $\mathrm{N}_{2}$ / Ar ratio were collected using Niskin bottles mounted on a CTD/Rosette system, which was equipped with pressure, temperature, conductivity, and oxygen sensors. $\mathrm{O}_{2}$ concentrations were determined using a Seabird sensor, calibrated using the Winkler method (precision of $0.45 \mu \mathrm{mol} \mathrm{L}^{-1}$ ) with a lower detection limit of $2 \mu \mathrm{mol} \mathrm{L}{ }^{-1}$. Nutrients concentrations were measured on board using standard methods as described in Stramma et al. (2013).

\section{2 $\mathrm{NO}_{2}^{-}$and $\mathrm{NO}_{3}^{-}$isotope analysis}

$\mathrm{NO}_{2}^{-}$samples were stored in $125 \mathrm{~mL}$ HDPE bottles preloaded with $2.25 \mathrm{~mL} 6 \mathrm{M} \mathrm{NaOH}$ to prevent microbial activity as well as alteration of $\delta^{18} \mathrm{O}-\mathrm{NO}_{2}^{-}$by isotope exchange with water (Casciotti et al., 2007). Bottles were kept frozen after sample collection, though we have subsequently determined in the laboratory that seawater samples preserved in this way can be kept at room temperature for at least a year without alteration of $\mathrm{NO}_{2}^{-} \delta^{15} \mathrm{~N}$ or $\delta^{18} \mathrm{O}$ (unpublished data). Samples were analyzed by continuous $\mathrm{He}$ flow isotope-ratio mass spectrometry (CF-IRMS; see below) after chemical conversion to $\mathrm{N}_{2} \mathrm{O}$ using acetic acid buffered sodium azide (Mcllvin and Altabet, 2005). Because of high sample $\mathrm{pH}$, the reagent was modified for $\mathrm{NO}_{2}^{-}$isotope analysis by increasing the acetic acid concentration to $7.84 \mathrm{M}$. In-house (i.e., MAA1, $\delta^{15} \mathrm{~N}=-60.6 \%$;
MAA2, $\left.\delta^{15} \mathrm{~N}=3.9 \% ; \mathrm{Zh} 1, \delta^{15} \mathrm{~N}=-16.4 \%\right)$ and other laboratory calibration standards $\left(\mathrm{N} 23, \delta^{15} \mathrm{~N}=3.7 \%\right.$ and $\delta^{18} \mathrm{O}=11.4 \%$; $\mathrm{N} 7373, \delta^{15} \mathrm{~N}=-79.6 \%$ and $\delta^{18} \mathrm{O}=4.5 \%$; and $\mathrm{N} 10219 ; \delta^{15} \mathrm{~N}=2.8 \%$ and $\delta^{18} \mathrm{O}=88.5 \%$; see Casciotti and McIlvin, 2007) were used for $\mathrm{NO}_{2}^{-} \delta^{15} \mathrm{~N}$ and $\delta^{18} \mathrm{O}$ analysis.

$\mathrm{NO}_{3}^{-}$samples were stored in $125 \mathrm{~mL}$ HDPE bottles preloaded with $1 \mathrm{~mL}$ of $2.5 \mathrm{mM}$ sulfamic acid in $25 \% \mathrm{HCl}$ to both act as a preservative and to remove $\mathrm{NO}_{2}^{-}$(Granger and Sigman, 2009). Samples were also kept at room temperature and we have found that they can be stored in this way for many years without alteration of $\mathrm{NO}_{3}^{-} \delta^{15} \mathrm{~N}$ or $\delta^{18} \mathrm{O}$. Cadmium reduction was used to convert $\mathrm{NO}_{3}^{-}$to $\mathrm{NO}_{2}^{-}$prior to conversion to $\mathrm{N}_{2} \mathrm{O}$ using the "azide method" (Mcllvin and Altabet, 2005) and IRMS analysis. Standards for $\mathrm{NO}_{3}^{-}$isotope analysis were $\mathrm{N} 3\left(\delta^{15} \mathrm{~N}=4.7 \%\right.$ and $\delta^{18} \mathrm{O}=25.6 \%$ ), USGS34 $\left(\delta^{15} \mathrm{~N}=-1.8 \%\right.$ and $\left.\delta^{18} \mathrm{O}=-27.9 \%\right)$, and USGS35 $\left(\delta^{15} \mathrm{~N}=2.7 \%\right.$ and $\delta^{18} \mathrm{O}=57.5 \%$ ) (Casciotti et al., 2007). The lowest concentration of $\mathrm{NO}_{2}^{-}$or $\mathrm{NO}_{3}^{-}$analyzed for isotopic composition was $0.5 \mu \mathrm{M}$, thus $\delta^{15} \mathrm{~N}_{-} \mathrm{NO}_{3}^{-}$ and $\delta^{15} \mathrm{~N}^{-\mathrm{NO}_{2}^{-}}$could not be measured below $37 \mathrm{~m}$ at station 63.

A GV Instruments IsoPrime Isotope Ratio Mass Spectrometer (IRMS) coupled to an on-line He continuous-flow purge and/or trap preparation system was used for isotope analysis (Sigman et al., 2001; Casciotti et al., 2002; Mcllvin and Altabet, 2005). $\mathrm{N}_{2} \mathrm{O}$ produced by the azide reaction was purged with $\mathrm{He}$ from the septum sealed $20 \mathrm{~mL}$ vials and trapped, cryofocused and purified prior to transfer to the IRMS. Total run time was $700 \mathrm{~s} \mathrm{sample}^{-1}$ (McIlvin and Altabet, 2005). Isotopic values are referenced against atmospheric $\mathrm{N}_{2}$ for $\delta^{15} \mathrm{~N}$ and VSMOW for $\delta^{18} \mathrm{O}$. Reproducibility was 0.2 and $0.5 \%$, respectively.

\section{$2.3 \quad \mathrm{~N}_{2}$ / Ar IRMS analysis and calculation of biogenic $\mathrm{N}_{2}$ and $\delta^{15} \mathrm{~N}$ biogenic $\mathrm{N}_{2}$}

The accumulation of biogenic $\mathrm{N}_{2}$ from denitrification and anammox can be measured directly from precise $\mathrm{N}_{2} / \mathrm{Ar}$ measurements (see above; Richards and Benson, 1961; Chang et al., 2010; Bourbonnais et al., 2015). As described in Charoenpong et al. (2014), $\mathrm{N}_{2}$ / Ar samples were collected from Niskin bottles using $125 \mathrm{~mL}$ serum bottles, and all samples were treated with $\mathrm{HgCl}_{2}$ as a preservative and filled without headspace. When cavitation bubbles formed from cooling of warm, near-surface samples, these bubbles were collapsed and reabsorbed by warming samples in the laboratory in a $30-35^{\circ} \mathrm{C}$ water bath before analysis. $\mathrm{N}_{2} / \mathrm{Ar}$ was measured using an automated dissolved gas extraction system coupled to a multicollector IRMS (Charoenpong et al., 2014). Excess $\mathrm{N}_{2}$ was calculated first from anomalies relative to $\mathrm{N}_{2} /$ Ar expected at saturation with atmosphere at in situ temperature and salinity. Locally produced biogenic $\mathrm{N}_{2}$ was obtained by subtracting excess $\mathrm{N}_{2}$ at the corresponding density surface for waters outside of the ODZ $\left(\mathrm{O}_{2}>10 \mu \mathrm{M}\right)$ 


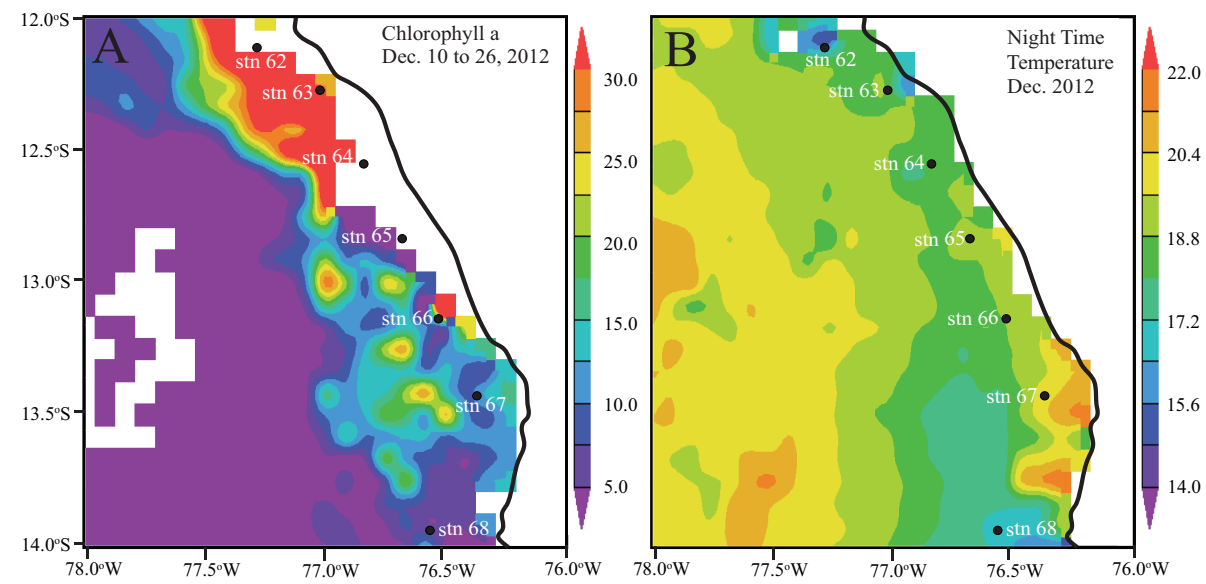

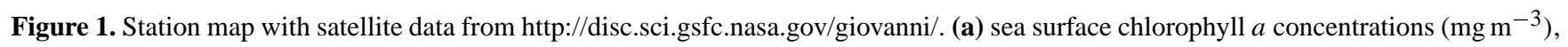
(b) nighttime sea surface temperature $\left({ }^{\circ} \mathrm{C}\right)$.

not affected by N-loss (Chang et al., 2010; Bourbonnais et al., 2015). $\delta^{15} \mathrm{~N}$ biogenic $\mathrm{N}_{2}$ was calculated from the $\delta^{15} \mathrm{~N}-$ $\mathrm{N}_{2}$ anomaly as in Bourbonnais et al. (2015). Reproducibility was better than $0.7 \mu \mathrm{M}$ for excess $\mathrm{N}_{2}$ and $0.03 \%$ for $\delta^{15} \mathrm{~N}$ $\mathrm{N}_{2} . \delta^{15} \mathrm{~N}$ of biogenic $\mathrm{N}_{2}$ was calculated by mass balance as in Bourbonnais et al. (2015).

\subsection{Isotope effect $(\varepsilon)$ calculations}

Isotope effects are estimated using the Rayleigh equations describing the change in isotope ratio as a function of fraction of remaining substrate. The following equations are used for a closed system (Mariotti et al., 1981):

$\delta^{15} \mathrm{~N}-\mathrm{NO}_{3}^{-}=\delta^{15} \mathrm{~N}-\mathrm{NO}_{3}^{-}(f=1)-\varepsilon \times \ln \left[f_{1}\right]$ or

$\delta^{15} \mathrm{~N}-\mathrm{DIN}=\delta^{15} \mathrm{~N}-\mathrm{DIN}(f=1)-\varepsilon \times \ln \left[f_{2}\right]$,

where $f_{1}$ is the fraction of remaining $\mathrm{NO}_{3}^{-}$and $f_{2}$ is the fraction of remaining DIN $\left(\mathrm{NO}_{3}^{-}+\mathrm{NO}_{2}^{-}\right.$concentrations). $\delta^{15} \mathrm{~N}$ DIN is the average $\delta^{15} \mathrm{~N}$ for $\mathrm{NO}_{3}^{-}$and $\mathrm{NO}_{2}^{-}$weighted by their concentrations. The fraction of remaining DIN is a better estimation of the overall effective isotope effect for $\mathrm{N}$-loss (Bourbonnais et al., 2015), while using $\mathrm{NO}_{3}^{-}$as the basis to calculate $\varepsilon$ specifically targets $\mathrm{NO}_{3}^{-}$reduction. See below for details of $f$ value calculation.

The overall isotope effect for N-loss can also be estimated from the $\delta^{15} \mathrm{~N}$ of biogenic $\mathrm{N}_{2}$ produced:

$$
\begin{aligned}
\delta^{15} \mathrm{~N}-\text { biogenic } \mathrm{N}_{2} & =\delta^{15} \mathrm{~N}-\mathrm{DIN}(f=1) \\
& +\varepsilon \times f_{2} /\left[1-f_{2}\right] \times \ln \left[f_{2}\right],
\end{aligned}
$$

whereas the closed system equations assume no addition or loss of substrate or product, corresponding steady-state open system equations can account for such effects (Altabet,
2005):

$\delta^{15} \mathrm{~N}-\mathrm{NO}_{3}^{-}=\delta^{15} \mathrm{~N}-\mathrm{NO}_{3}^{-}(f=1)+\varepsilon\left[1-f_{1}\right]$ or

$\delta^{15} \mathrm{~N}-\mathrm{DIN}=\delta^{15} \mathrm{~N}-\mathrm{DIN}(f=1)+\varepsilon \times\left[1-f_{2}\right]$

$\delta^{15} \mathrm{~N}$-biogenic $\mathrm{N}_{2}=\delta^{15} \mathrm{~N}-\mathrm{DIN}(f=1)-\varepsilon \times f_{2}$.

For all equations, the slope represents $\varepsilon$ and the $y$ intercept is the initial $\delta^{15} \mathrm{~N}$ prior to $\mathrm{N}$-loss. For calculations using Eqs. (3) and (6) we only used $\delta^{15} \mathrm{~N}$ values associated with biogenic $\mathrm{N}_{2}$ greater than $7.5 \mu \mathrm{M}$ because of increasing noise below this level due to the large atmospheric dissolved $\mathrm{N}_{2}$ background (typically up to $\sim 500 \mu \mathrm{M}$ ).

Since the closed system equations assume no loss or resupply of substrate or production in a water parcel, they are appropriate where there is little mixing and/or advection is dominant over mixing. The open system equations take into account supply from or loss to surrounding water parcels, e.g. mixing dominance. Both cases represent extreme situations. In the next section, we will estimate and compare $\varepsilon$ using both sets of equations.

To do so, we need to estimate the fraction of $\mathrm{NO}_{3}^{-}$or DIN remaining $(f)$. The assumption of Redfield stoichiometry (as in Eq. 9) in source waters is typically made:

$$
\begin{aligned}
& f_{1 \mathrm{p}}=\left[\mathrm{NO}_{3}^{-}\right] / \mathrm{Np}_{\text {expected }} \text { or } \\
& f_{2 \mathrm{p}}=\left(\left[\mathrm{NO}_{3}^{-}\right]+\left[\mathrm{NO}_{2}^{-}\right]\right) / \mathrm{Np}_{\text {expected }} \\
& \mathrm{Np}_{\text {expected }}=15.8 \cdot\left(\left[\mathrm{PO}_{4}^{3-}\right]-0.3\right) \\
& \mathrm{N}_{\text {observed }}=\left[\mathrm{NO}_{3}^{-}\right]+\left[\mathrm{NO}_{2}^{-}\right]+\left[\mathrm{NH}_{4}^{+}\right],
\end{aligned}
$$

where $\mathrm{Np}_{\text {expected }}$ is the concentration expected assuming Redfield stoichiometry. Equation (9) was derived in Chang et al. (2010) from stations to the west of the ETSP ODZ (143$\left.146^{\circ} \mathrm{W}\right)$ and takes into account preformed nutrient concentrations. In our study, $\mathrm{NH}_{4}^{+}$generally did not significantly accumulate, except at station 63, and was thus not included. 
This has been the traditional approach to quantify N-loss in ODZs ( $\mathrm{N}$ deficit, $\mathrm{Np}_{\mathrm{def}}$ ), by comparing observed DIN concentrations $\left(\mathrm{N}_{\text {observed }}\right)$ to $\mathrm{Np}_{\text {expected }}$ :

$\mathrm{Np}_{\text {def }}=\mathrm{Np}_{\text {expected }}-\mathrm{N}_{\text {observed }}$

However, the assumption of Redfield stoichiometry may not be appropriate in this shallow environment due to preferential release of $\mathrm{PO}_{4}^{3-}$ following iron and manganese oxyhydroxide dissolution in anoxic sediments (e.g., Noffke et al., 2012). An alternative method of calculating $f$ makes use of our biogenic $\mathrm{N}_{2}$ measurements to estimate expected $\mathrm{N}$ prior to $\mathrm{N}$-loss $\left(\mathrm{N}_{\text {expected }}-\right.$ bio $\left.\mathrm{N}_{2}\right)$ and $f$ values based on it:

$\mathrm{N}_{\text {expected }}-$ bio $\mathrm{N}_{2}=\left[\mathrm{NO}_{3}^{-}\right]+\left[\mathrm{NO}_{2}^{-}\right]+2 \times\left[\right.$ Biogenic $\left.\mathrm{N}_{2}\right]$

$f_{1 \text { bioN }}=\left[\mathrm{NO}_{3}^{-}\right] / \mathrm{N}_{\text {expected }}-$ bioN $_{2}$ or

$f_{2 \text { bioN }_{2}}=\left[\mathrm{NO}_{3}^{-}+\mathrm{NO}_{2}^{-}\right] / \mathrm{N}_{\text {expected }}-$ bio $\mathrm{N}_{2}$.

A third way to estimate $f$ is to use $\mathrm{NO}_{3}^{-}$or DIN concentrations divided by observed maximum $\mathrm{NO}_{3}^{-}$or DIN concentrations for the source of the upwelled waters (see red rectangles in Fig. 2).

\section{Results}

\subsection{Hydrographic characterization}

During the study period, there was active coastal upwelling especially at station 63 as seen by relatively low satellite sea surface temperatures, higher chlorophyll $a$ concentrations, and a shallow oxycline (Fig. 1). A common relationship and narrow range for $T$ and $S$ were found, comparable to $T / S$ signatures for offshore ODZ waters between $\sim 100$ and $200 \mathrm{~m}$ depths (Bourbonnais et al. 2015), indicating a common source of water upwelling at these inner shelf stations (Fig. 2). This is expected in these shallow waters, where upwelling of the Peru coastal current with low $\mathrm{O}_{2}$ and high nutrients plays a dominant role (Penven et al., 2005). $\mathrm{O}_{2}$ increased only in warmer near-surface waters as a consequence of atmospheric exchange. There was a change in surface water temperature from 15 to $20^{\circ} \mathrm{C}$ (Fig. 1b) with distance along the coast (from 12.0 to $14.0^{\circ} \mathrm{S}$, about $222 \mathrm{~km}$ ) that indicates corresponding changes in upwelling intensity. Stronger local wind forcing likely brought up colder deep water near station 63 .

\subsection{Dissolved $\mathrm{O}_{2}$ and nutrient concentrations}

As a consequence of active upwelling sourced from the offshore ODZ, the oxycline was very shallow at our inshore stations. $\mathrm{O}_{2}$ was generally depleted below 10 to $20 \mathrm{~m}$ (Fig. 3a) and was always less than $10 \mu \mathrm{M}$ below $30 \mathrm{~m}$. Because we are focusing on $\mathrm{N}$-transformations that occur in the absence of $\mathrm{O}_{2}$, our data analyses will be mainly restricted to samples where $\mathrm{O}_{2}$ concentration is below this value. Whereas a recent study indicates that denitrification and anammox are reversibly suppressed at nanomolar $\mathrm{O}_{2}$ levels (Dalsgaard et al., 2014), CTD deployed Seabird $\mathrm{O}_{2}$ sensors are not sufficiently sensitive to detect such low concentrations and hence our choice of a $10 \mu \mathrm{M}$ threshold. In contrast, $\mathrm{NO}_{2}^{-}$oxidation, an aerobic process, was shown to occur even at low to non-detectable $\mathrm{O}_{2}$ (Füssel et al., 2012).

Both $\mathrm{Si}(\mathrm{OH})_{4}$ and $\mathrm{PO}_{4}^{3-}$ concentrations had very similar vertical and along section distributions (Fig. 3c, d). Concentrations were at a minimum at the surface, presumably due to phytoplankton uptake, and increased with depth to up to 46 and $3.7 \mu \mathrm{M}$, respectively. Station 63 had the highest nearbottom concentrations, a likely result of release from the sediments, which is futher supported by high near-bottom $\mathrm{NH}_{4}^{+}$ concentrations (up to $\sim 4 \mu \mathrm{M}$ ) as compared to the other stations (Fig. 3b, c, d).

In contrast to other nutrients, $\mathrm{NO}_{3}^{-}$and $\mathrm{NO}_{2}^{-}$concentrations were lowest near-bottom at station 63 , only reaching their maxima above $60 \mathrm{~m}$. Across most of our stations, $\mathrm{NO}_{3}^{-}$ concentration was $22 \mu \mathrm{M}$ at 20 to $40 \mathrm{~m}$ depth but decreased to near zero deeper within the $\mathrm{O}_{2}$-depleted zone due to microbially mediated $\mathrm{NO}_{3}^{-}$reduction (Fig. 4a). $\mathrm{NO}_{2}^{-}$concentrations correspondingly ranged from 6 to $11 \mu \mathrm{M}$ for $\mathrm{O}_{2}$ concentrations less than $10 \mu \mathrm{M}$ (Fig. 4b). The highest $\mathrm{NO}_{2}^{-}$concentration $(11 \mu \mathrm{M})$ was found at around $50 \mathrm{~m}$ (station 64$)$, but only reached $6 \mu \mathrm{M}$ at all other stations.

\section{3 $\mathrm{NO}_{2}^{-}$and $\mathrm{NO}_{3}^{-}$isotope compositions}

As a consequence of kinetic isotope fractionation during $\mathrm{N}$ loss, the $\mathrm{N}$ and $\mathrm{O}$ isotope composition of $\mathrm{NO}_{3}^{-}$and $\mathrm{NO}_{2}^{-}$varied inversely with $\mathrm{NO}_{3}^{-}$and $\mathrm{NO}_{2}^{-}$concentrations, with maximum $\delta^{15} \mathrm{~N}$ and $\delta^{18} \mathrm{O}$ values near the bottom at each station. $\delta^{15} \mathrm{~N}-\mathrm{NO}_{3}^{-}$increased from about $10 \%$ in surface waters to up to $50 \%$ in the $\mathrm{O}_{2}$-depleted zone (Fig. 4c), with near bottom values at station 64 significantly higher $(50 \%$ o) than at the other stations which ranged from 20 to $30 \%$. $\delta^{15} \mathrm{~N}-\mathrm{NO}_{2}^{-}$ varied from -25 to about $10 \%$ (Fig. $4 \mathrm{~d}$ ), with maximum values also in deeper waters at station 64 .

As expected for $\mathrm{NO}_{3}^{-}$reduction, $\delta^{18} \mathrm{O}-\mathrm{NO}_{3}^{-}$positively covaried with $\delta^{15} \mathrm{~N}-\mathrm{NO}_{3}^{-}$and ranged from 12 to $46 \%$. We observed an overall linear relationship between $\delta^{15} \mathrm{~N}-\mathrm{NO}_{3}^{-}$ and $\delta^{18} \mathrm{O}-\mathrm{NO}_{3}^{-}$with a slope of 0.86 , which was significantly different than 1 ( $p$ value $<0.05$ ), and a $y$ intercept of $1.90\left(r^{2}=0.996\right.$, see Fig. 5a). $\mathrm{NO}_{3}^{-} \delta^{15} \mathrm{~N}$ and $\delta^{18} \mathrm{O}$ have been shown to increase equally (ratio $1: 1$ ) during assimilatory and dissimilatory $\mathrm{NO}_{3}^{-}$reduction (Casciotti et al., 2002; Granger et al., 2004, 2008). However, deviations from this trend have been observed in the ocean and interpreted as evidence for co-occurring $\mathrm{NO}_{3}^{-}$production processes (Sigman et al., 2005; Casciotti and McIlvin, 2007; Bourbonnais et al., $2009,2015)$. In this study, we observed a $\mathrm{NO}_{3}^{-} \delta^{18} \mathrm{O}$ vs. $\delta^{15} \mathrm{~N}$ 


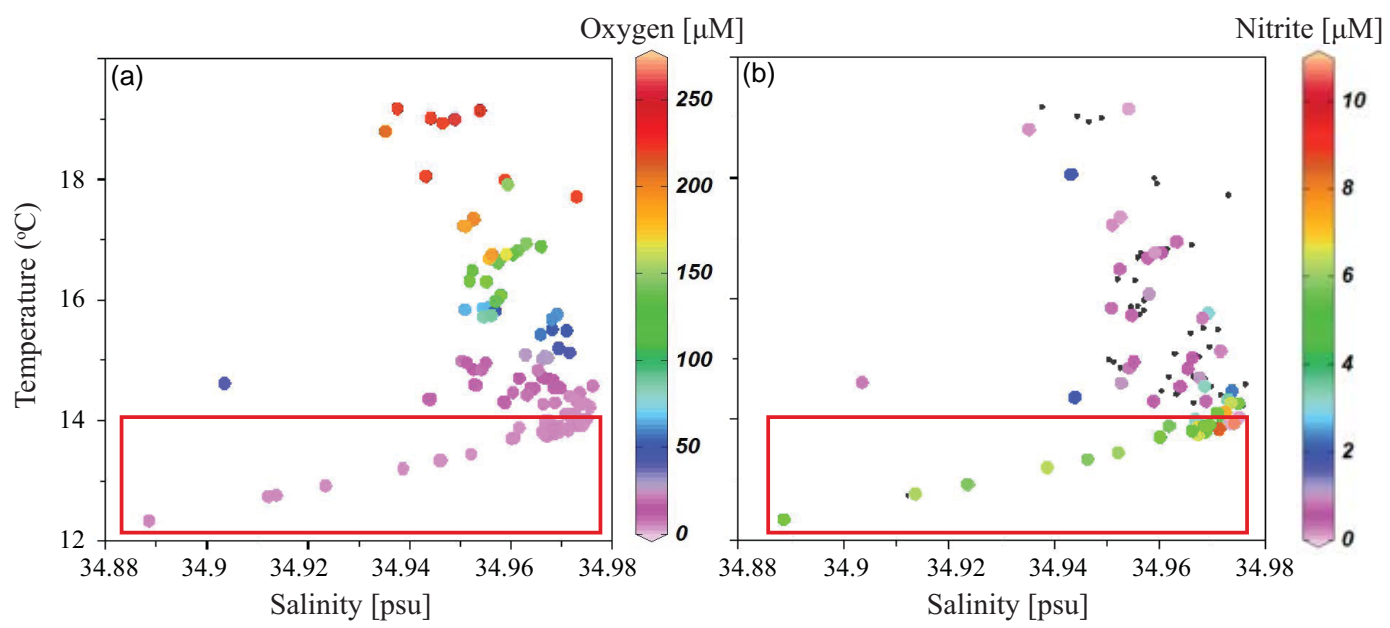

Figure 2. Temperature vs. salinity plots. In (a), color indicates $\mathrm{O}_{2}$ concentration $(\mu \mathrm{M})$. In (a), color indicates $\mathrm{NO}_{2}^{-}$concentration $(\mu \mathrm{M})$. Black dots in (b) mean no $\mathrm{NO}_{2}^{-}$concentration data are available. Points in red rectangle at bottom of each plot belong to station 68 for depths greater than $150 \mathrm{~m}$.
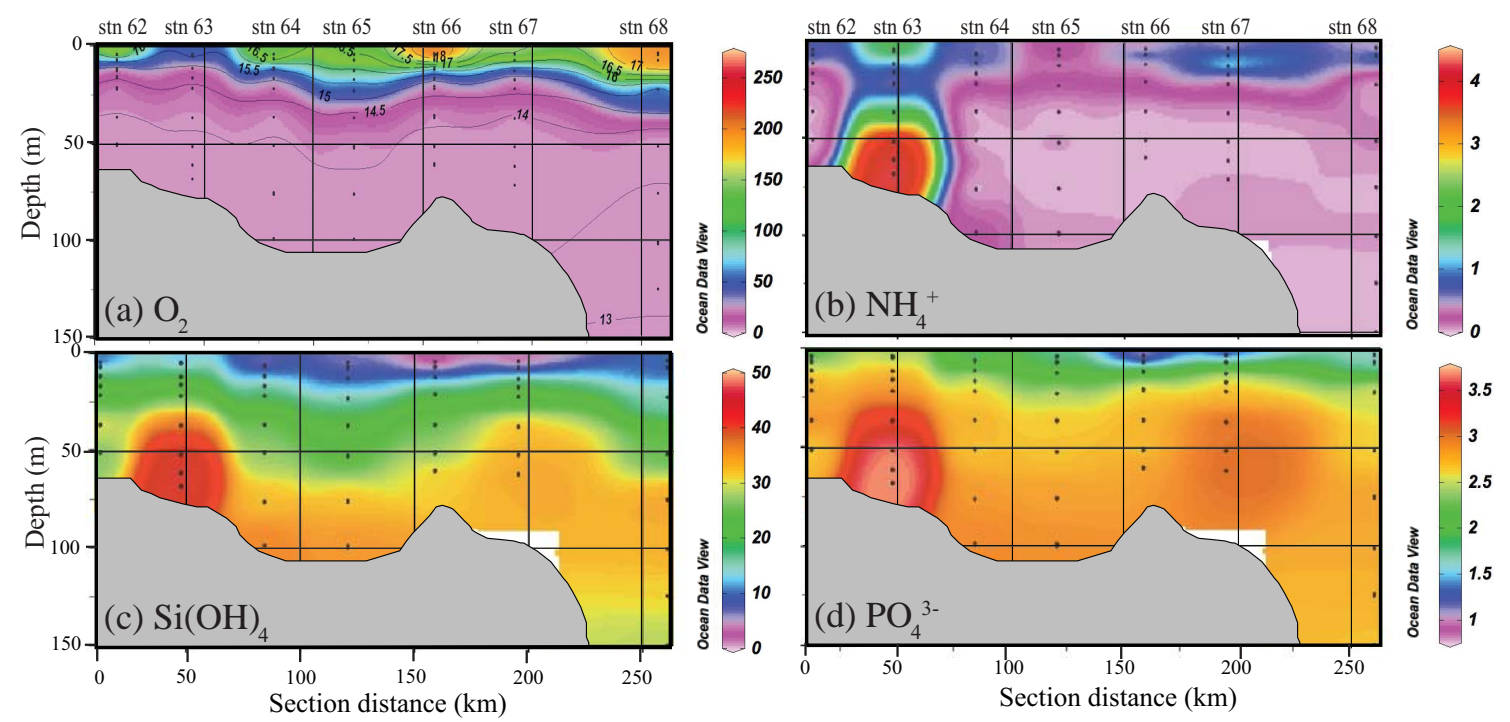

Figure 3. $\mathrm{O}_{2}$ and nutrient distribution along the transect. (a) $\mathrm{O}_{2}$ concentration $(\mu \mathrm{M})$ with isotherm overlay, (b) $\mathrm{NH}_{4}^{+}$concentration $(\mu \mathrm{M})$, (c) $\mathrm{Si}(\mathrm{OH})_{4}$ concentration $(\mu \mathrm{M})$ and (d) $\mathrm{PO}_{4}^{3-}$ concentration $(\mu \mathrm{M})$. Grey region represents bathymetry. The depth for station 68 is $253 \mathrm{~m}$.

relationship less than 1 , likely originating from $\mathrm{NO}_{2}^{-}$reoxidation to $\mathrm{NO}_{3}^{-}$in our environmental setting as in Casciotti and McIlvin (2007). We also observed, for the first time, a significant correlation between $\delta^{15} \mathrm{~N}^{-\mathrm{NO}_{2}^{-}}$and $\delta^{18} \mathrm{O}-\mathrm{NO}_{2}^{-}$in the ODZ for our in-shore water stations (Fig. 5b). As in prior studies (Casciotti and McIlvin, 2007; Casciotti et al., 2013), no such relationship was observed by us for a nearby set of offshore stations (see Fig. 5c) where longer $\mathrm{NO}_{2}^{-}$turnover times likely facilitated $\mathrm{O}$ isotope exchange with water. We will discuss implications of this unique finding in the next section.

\subsection{The $\delta^{15} \mathrm{~N}$ difference between $\mathrm{NO}_{3}^{-}$and $\mathrm{NO}_{2}^{-}$}

The difference in $\delta^{15} \mathrm{~N}$ between $\mathrm{NO}_{3}^{-}$and $\mathrm{NO}_{2}^{-}\left(\Delta \delta^{15} \mathrm{~N}\right)$ reflects the combined isotope effects of simultaneous $\mathrm{NO}_{3}^{-}$reduction, $\mathrm{NO}_{2}^{-}$reduction, and $\mathrm{NO}_{2}^{-}$oxidation. For $\mathrm{NO}_{3}^{-}$reduction alone, highest $\Delta \delta^{15} \mathrm{~N}$ values would be around $25 \%$ o at steady-state (Cline and Kaplan, 1975; Brandes et al., 1998; Voss et al., 2001; Granger et al., 2004, 2008). The effect of $\mathrm{NO}_{2}^{-}$reduction would be to increase the $\delta^{15} \mathrm{~N}$ of the residual $\mathrm{NO}_{2}^{-}$, thus decreasing $\Delta \delta^{15} \mathrm{~N}$. In contrast, $\mathrm{NO}_{2}^{-}$oxidation is associated with an inverse kinetic isotope effect (Casciotti, 2009) which acts to decrease the residual $\delta^{15} \mathrm{~N}_{\text {of }} \mathrm{NO}_{2}^{-}$ 

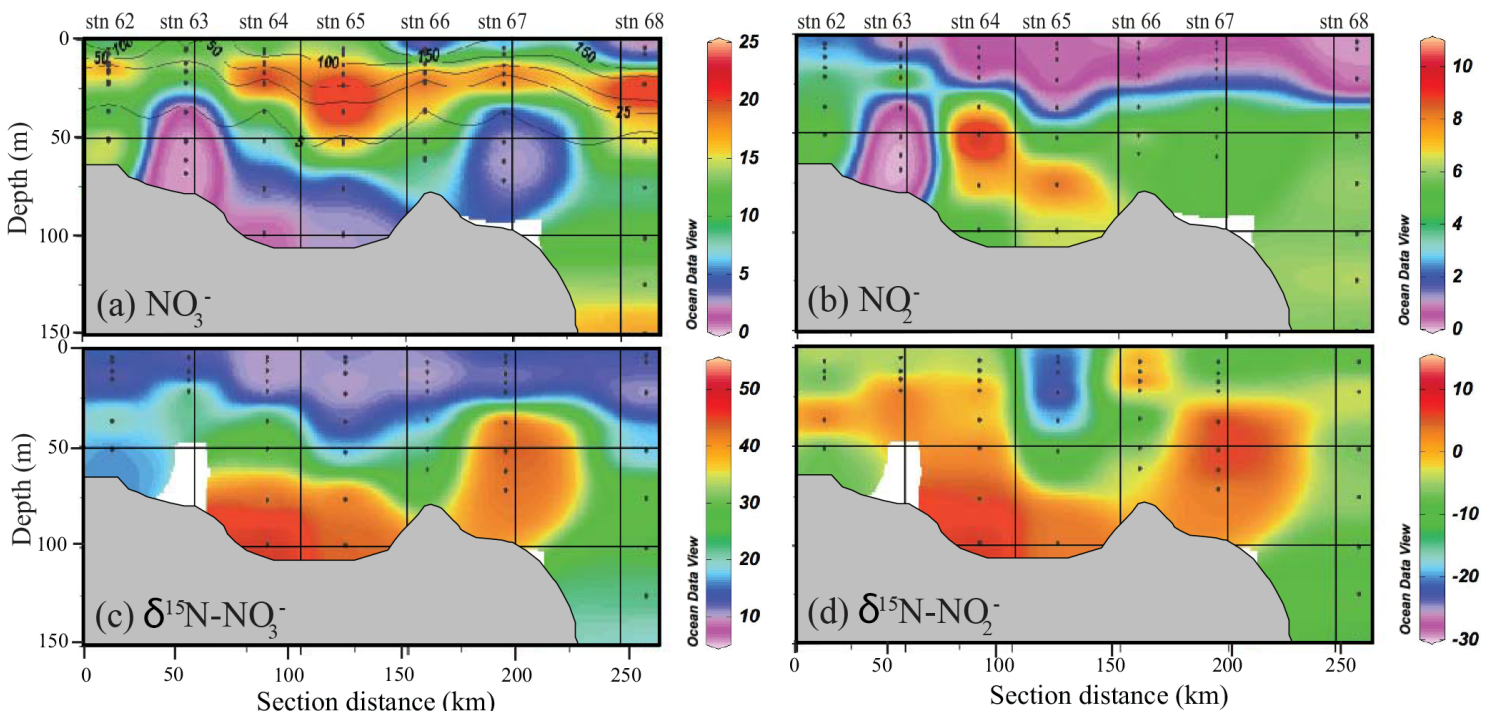

Figure 4. Transects off the Peru coast for (a) $\mathrm{NO}_{3}^{-}$concentration $(\mu \mathrm{M})$ with $\mathrm{O}_{2}$ overlay, (b) $\mathrm{NO}_{2}^{-}$concentration $(\mu \mathrm{M})$, (c) $\delta^{15} \mathrm{~N}_{-} \mathrm{NO}_{3}^{-}(\%$ o) and (d) $\delta^{15} \mathrm{~N}_{-\mathrm{NO}_{2}^{-}}^{-}(\% \circ)$. Gray region represents approximate bathymetry. No isotopic data are available for the deeper samples collected at station 63 , because $\mathrm{NO}_{3}^{-}$and $\mathrm{NO}_{2}^{-}$concentrations were below analytical limits $(<0.5 \mu \mathrm{M})$.

and hence overall increases the $\Delta \delta^{15} \mathrm{~N}$. Therefore, following $\mathrm{NO}_{2}^{-}$oxidation, $\Delta \delta^{15} \mathrm{~N}$ may be larger than expected from $\mathrm{NO}_{3}^{-}$and $\mathrm{NO}_{2}^{-}$reduction alone, especially if the system is not at steady-state (Casciotti et al., 2013). $\Delta \delta^{15} \mathrm{~N}$ ranged from 15 to $40 \%$ (average $=29.78 \%$ and median $=32.5 \%$ ) for samples with $\mathrm{O}_{2}<10 \mu \mathrm{M}$. These results confirm the presence of $\mathrm{NO}_{2}^{-}$oxidation for at least some of our depth intervals.

\subsection{N deficit, biogenic $\mathrm{N}_{2}$ and $\delta^{15} \mathrm{~N}-\mathrm{N}_{2}$}

$\mathrm{N}$ deficits, biogenic $\mathrm{N}_{2}$ concentrations, and $\delta^{15} \mathrm{~N}-\mathrm{N}_{2}$ anomalies relative to equilibrium with atmosphere were overall greater in the $\mathrm{O}_{2}$-depleted zone reaching highest values near the bottom of station 63 (Fig. 7). N deficit, calculated assuming Redfield stoichiometry (Eqs. 9 to 11), ranged from 17 to $59 \mu \mathrm{M}$ in this region. The concentration of biogenic $\mathrm{N}$ in $\mathrm{N}_{2}$ ranged from 12 to $36 \mu \mathrm{M}-\mathrm{N}$ and, as expected, was strongly linearly correlated with $\mathrm{N}$ deficit $\left(r^{2}=0.87\right.$; Fig. 8c). However, the slope of 0.45 for the linear relationship shows biogenic $\mathrm{N}$ in $\mathrm{N}_{2}$ to be only half that expected from $\mathrm{Np}_{\text {def }}$, a possible consequence of benthic $\mathrm{PO}_{4}^{3-}$ release. The linear relationship $\left(r^{2}=0.91\right)$ observed between biogenic $\mathrm{N}$ in $\mathrm{N}_{2}$ and DIN (Fig. 8a) supports a single initial DIN value for the source waters to our stations and hence validates using this as a basis for calculating $f$. The slope of the correlation (0.74) is much closer to 1 as compared to the correlation with $\mathrm{Np}_{\mathrm{def}}$, further supporting excess $\mathrm{PO}_{4}^{-3}$ as a contributor to the latter. However this value is still significantly less than 1 , suggesting that biogenic $\mathrm{N}$ in $\mathrm{N}_{2}$ may also be underestimated. Because our data are restricted to $\mathrm{O}_{2}$-depleted depths, it is unlikely that biogenic $\mathrm{N}_{2}$ was lost to the atmosphere. Al- ternatively, mixing of water varying in $\mathrm{N}_{2} / \mathrm{Ar}$ can result in such underestimates of biogenic $\mathrm{N}_{2}$ when $\mathrm{N}_{2} / \mathrm{Ar}$ anomalies are used to calculate excess $\mathrm{N}_{2}$ (see Charoenpong et al., 2014). As seen below, our estimates of $\varepsilon$ are rather insensitive to choice of $\mathrm{Np}_{\text {def }}$, biogenic $\mathrm{N}$ in $\mathrm{N}_{2}$, or DIN concentration changes as the basis for calculation of $f$.

The $\delta^{15} \mathrm{~N}-\mathrm{N}_{2}$ anomaly, i.e., the difference between the $\delta^{15} \mathrm{~N}-\mathrm{N}_{2}$ observed and at equilibrium, derived as in Charoenpong et al. (2014), ranged from -0.2 to $0.1 \%$ (Fig. 7c). The corresponding range in $\delta^{15} \mathrm{~N}$ biogenic $\mathrm{N}_{2}$ at $\mathrm{O}_{2}<10 \mu \mathrm{M}$ was from -9.0 to $3.2 \%$. Negative $\delta^{15} \mathrm{~N}-\mathrm{N}_{2}$ anomaly (i.e., lower $\delta^{15} \mathrm{~N}$-biogenic $\mathrm{N}_{2}$ ) is produced at the onset of $\mathrm{N}$-loss, because extremely depleted ${ }^{15} \mathrm{~N}-\mathrm{N}_{2}$ is first produced. At a more advanced $\mathrm{N}$-loss stage, we expect $\delta^{15} \mathrm{~N}-\mathrm{N}_{2}$ anomaly and $\delta^{15} \mathrm{~N}$-biogenic $\mathrm{N}_{2}$ to increase, which we observed in this study, as heavier ${ }^{15} \mathrm{~N}$ is added to the biogenic $\mathrm{N}_{2}$ pool. The $\delta^{15} \mathrm{~N}-\mathrm{N}_{2}$ anomaly signal appears small when compared to the isotopic composition of $\mathrm{NO}_{3}^{-}$and $\mathrm{NO}_{2}^{-}$but is (1) analytically significant and (2) the result of dilution by the large background of atmospheric $\mathrm{N}_{2}\left(400\right.$ to $\left.500 \mu \mathrm{M} \mathrm{N}_{2}\right)$.

\subsection{Isotope effect $(\varepsilon)$}

Isotope effects were calculated using Eqs. (1) to (6) to compare closed vs. open system assumptions as well as different approaches to estimating $f$. Examples of plots of the closed system equations with $f$ calculated using biogenic $\mathrm{N}_{2}$, are shown in Fig. 6. Comparison of results using all three approaches for calculating $f$ (i.e. Redfield stoichiometry, biogenic $\mathrm{N}_{2}$ and observed substrate divided by maximum "upwelled" concentration, (see Sect. 2.4)) are shown in Table 1 (closed system) and 2 (open system). In the case of the closed 

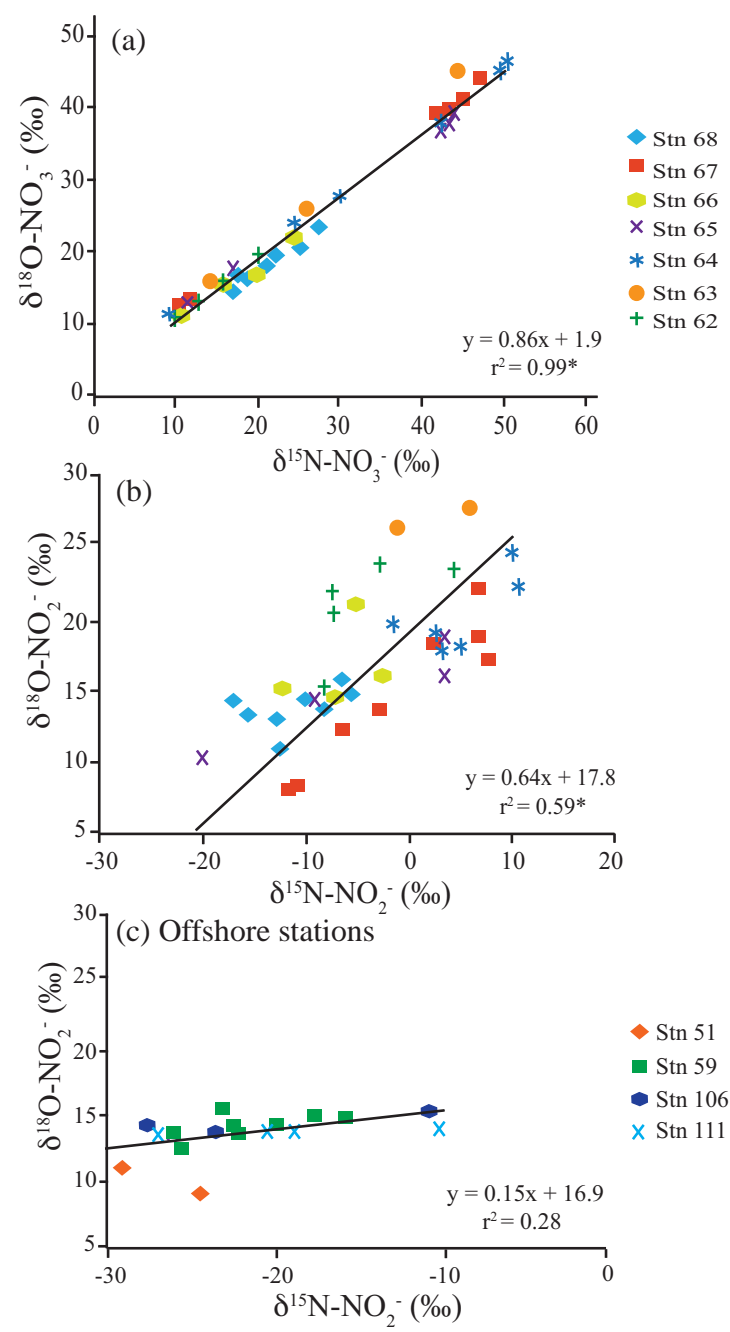

Figure 5. Relationships between $\delta^{15} \mathrm{~N}$ and $\delta^{18} \mathrm{O}$ for $\mathrm{NO}_{3}^{-}$and $\mathrm{NO}_{2}^{-}$, respectively, for $\mathrm{O}_{2} \leq 10 \mu \mathrm{M}$. (a) $\delta^{18} \mathrm{O}-\mathrm{NO}_{3}^{-}$vs. $\delta^{15} \mathrm{~N}-\mathrm{NO}_{3}^{-}$ for station 62 to 68 . (b) $\delta^{18} \mathrm{O}-\mathrm{NO}_{2}^{-}$vs. $\delta^{15} \mathrm{~N}-\mathrm{NO}_{2}^{-}$for station 62 to 68 . (c) $\delta^{18} \mathrm{O}-\mathrm{NO}_{2}^{-}$vs. $\delta^{15} \mathrm{~N}-\mathrm{NO}_{2}^{-}$for M90 offshore stations 51 , 59, 106 and 111 (see text, Sect. 3.3). For each plot, overall linear regressions are shown. Significant correlation coefficients at a 0.05 significance level are denoted by *.

system, $\varepsilon$ values were in all cases lower than canonical ones, ranging narrowly from $\sim 6 \%$ o for changes in the $\delta^{15} \mathrm{~N}$ of DIN to $\sim 14 \%$ o for changes in $\delta^{15} \mathrm{~N}-\mathrm{NO}_{3}^{-}$(Table 1 ). For the open system equations, estimated $\varepsilon$ was higher and covered a large and unrealistic range from $\sim 12 \%$ o for changes in the biogenic $\mathrm{N}_{2}$ to $\sim 63 \%$ ofor changes in the $\delta^{15} \mathrm{~N}$ of $\mathrm{NO}_{3}^{-}$. For our inshore water stations, where we observed a single water mass (Fig. 2), a closed system should be a more realistic approximation of $\varepsilon$. The Rayleigh equations' $y$ intercepts, where $f=1$, represent the initial $\delta^{15} \mathrm{~N}$ of $\mathrm{NO}_{3}^{-}$or DIN, and varied from -0.5 to 10.9 and -21.9 to $8.5 \%$ o for closed and open systems, respectively. The higher end of this range
Table 1. $\varepsilon$ for $\mathrm{NO}_{3}^{-}$reduction and net $\mathrm{N}$ loss estimated from both DIN consumption and produced biogenic $\mathrm{N}_{2}$ using Rayleigh closed system equations (Eqs. 1-3). Results are calculated for $f$ based on either $\mathrm{Np}_{\text {expected }}$ (Eqs. 7-9), biogenic $\mathrm{N}_{2}$ (Eqs. 12-14) and measured substrate divided by maximum (upwelled) substrate concentrations (see text, Sect. 2.4). The standard error of the slope $(\varepsilon)$ is shown.

\begin{tabular}{|c|c|c|c|c|}
\hline & Basis for $f$ & $\varepsilon$ & $y$ intercept & $r^{2}$ \\
\hline \multirow[t]{3}{*}{$\delta^{15} \mathrm{~N}-\mathrm{NO}_{3}^{-}$} & $\mathrm{Np}_{\text {expected }}$ & $13.9 \pm 0.7$ & 3.74 & 0.92 \\
\hline & $\mathrm{N}_{2}$ Biogenic & $14.3 \pm 0.9$ & 3.71 & 0.95 \\
\hline & {$\left[\mathrm{NO}_{3}^{-}\right] /\left[\mathrm{NO}_{3}^{-}\right]_{\max }$} & $14.7 \pm 0.6$ & -0.55 & 0.95 \\
\hline \multirow[t]{3}{*}{$\delta^{15} \mathrm{~N}-\mathrm{DIN}$} & $\mathrm{Np}_{\text {expected }}$ & $6.3 \pm 0.3$ & 7.20 & 0.92 \\
\hline & $\mathrm{N}_{2}$ Biogenic & $6.6 \pm 0.4$ & 6.71 & 0.94 \\
\hline & $\mathrm{DIN} / \mathrm{DIN}_{\max }$ & $7.4 \pm 0.6$ & 10.90 & 0.91 \\
\hline \multirow[t]{2}{*}{$\delta^{15} \mathrm{~N}$-Biogenic $\mathrm{N}_{2}$} & $\mathrm{~Np}_{\text {expect }}$ & $10.5 \pm 1.5$ & 2.94 & 0.70 \\
\hline & $\mathrm{N}_{2}$ Biogenic & $10.6 \pm 1.5$ & 3.04 & 0.72 \\
\hline
\end{tabular}

is more realistic based on prior isotopic measurements for source waters (e.g., Bourbonnais et al., 2015).

\section{Discussion}

\subsection{Behavior of $\mathrm{NO}_{2}^{-}$}

$\mathrm{NO}_{2}^{-}$is an important intermediate during either oxidative or reductive $\mathrm{N}$-cycle pathways and can accumulate at relatively high concentrations through the ocean. While $\mathrm{NO}_{2}^{-}$is generally elevated at the base of the sunlit euphotic zone (i.e. primary $\mathrm{NO}_{2}^{-}$maximum; Dore and Karl, 1996; Lomas and Lipschultz, 2006), highest concentrations are found in ODZ's as part of the secondary $\mathrm{NO}_{2}^{-}$maximum (Codispoti and Christensen 1985; Lam et al., 2011). Accordingly, high $\mathrm{NO}_{2}^{-}$concentrations ranging from 7.2 to $10.7 \mu \mathrm{M}$ were observed at $50-75 \mathrm{~m}$ depth in coastal $\mathrm{O}_{2}$-depleted waters in this study as a likely consequence of dissimilatory $\mathrm{NO}_{3}^{-}$reduction (e.g., Lipschultz et al., 1990; Lam et al., 2009; Kalvelage et al., 2013).

To assess the influence of the various $\mathrm{N}$ cycle processes that have $\mathrm{NO}_{2}^{-}$as either a substrate or product, we first examined the relationship between the $\delta^{15} \mathrm{~N}$ and $\delta^{18} \mathrm{O}$ of $\mathrm{NO}_{2}^{-}$. Several processes can influence the isotopic composition of $\mathrm{NO}_{2}^{-} . \mathrm{NO}_{3}^{-}$reduction to $\mathrm{NO}_{2}^{-}$is associated with a $\varepsilon$ of 20 to $30 \%$ (Cline and Kaplan, 1975; Brandes et al., 1998; Voss et al., 2001; Granger et al., 2004, 2008) and acts to produce $\mathrm{NO}_{2}^{-}$depleted in ${ }^{15} \mathrm{~N}$ and ${ }^{18} \mathrm{O}$. In contrast, $\mathrm{NO}_{2}^{-}$reduction as part of either anammox, denitrification or DNRA increases both the $\delta^{15} \mathrm{~N}$ and $\delta^{18} \mathrm{O}$ of residual $\mathrm{NO}_{2}^{-}$, with laboratory and field estimates for $\varepsilon$ clustering around 12 to $16 \%$ o (Bryan et al., 1983; Brunner et al., 2013; Bourbonnais et al., 2015). However, $\mathrm{NO}_{2}^{-}$oxidation to $\mathrm{NO}_{3}^{-}$at low or non-detectable $\mathrm{O}_{2}$ has been shown to be an important sink for $\mathrm{NO}_{2}^{-}$in ODZs (e.g. Füssel et al., 2012). Anammox bacteria can also use 

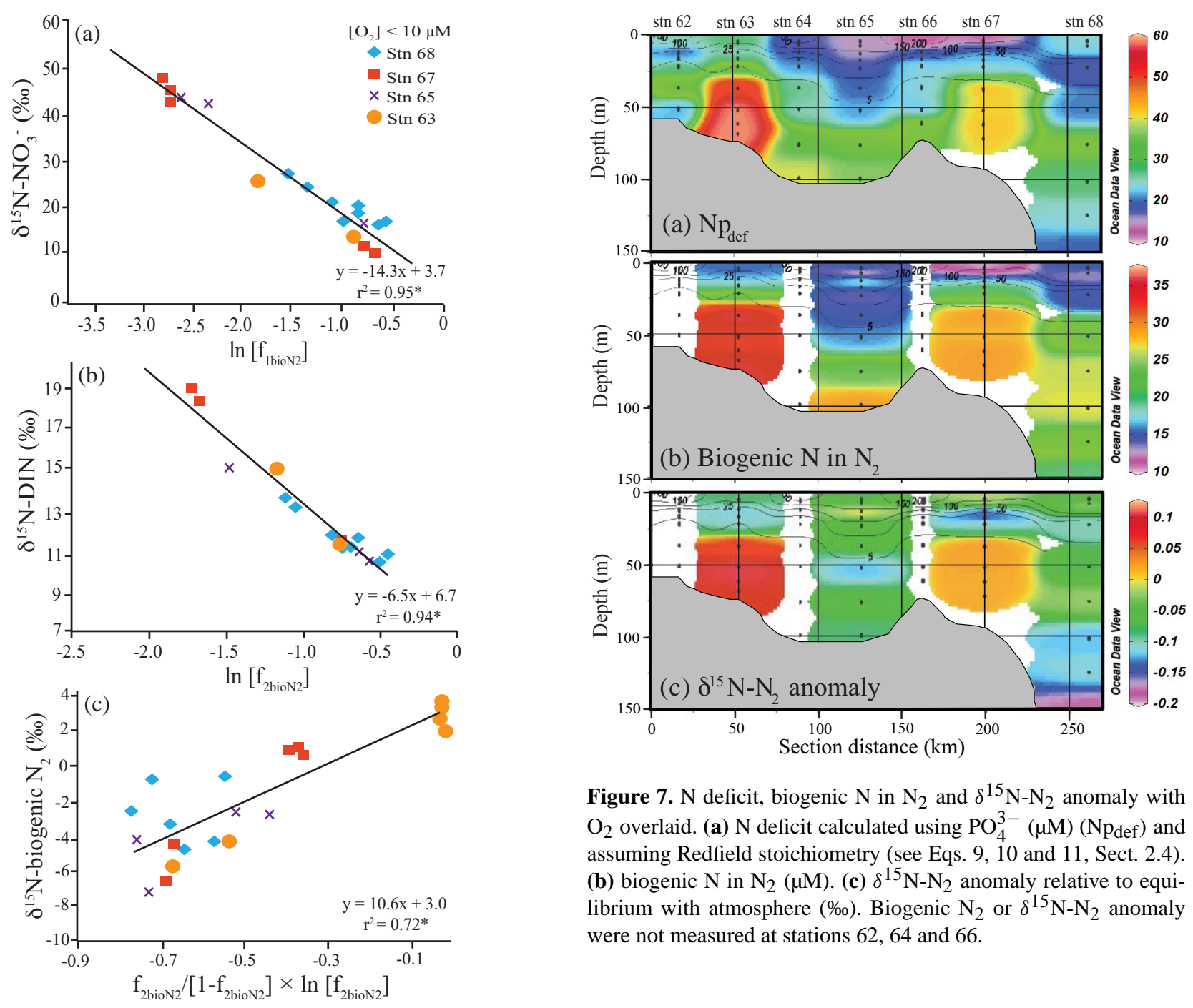

Figure 7. $\mathrm{N}$ deficit, biogenic $\mathrm{N}$ in $\mathrm{N}_{2}$ and $\delta^{15} \mathrm{~N}-\mathrm{N}_{2}$ anomaly with $\mathrm{O}_{2}$ overlaid. (a) $\mathrm{N}$ deficit calculated using $\mathrm{PO}_{4}^{3-}(\mu \mathrm{M})\left(\mathrm{Np}_{\mathrm{def}}\right)$ and assuming Redfield stoichiometry (see Eqs. 9, 10 and 11, Sect. 2.4). (b) biogenic $\mathrm{N}$ in $\mathrm{N}_{2}(\mu \mathrm{M})$. (c) $\delta^{15} \mathrm{~N}-\mathrm{N}_{2}$ anomaly relative to equilibrium with atmosphere $(\% \circ)$. Biogenic $\mathrm{N}_{2}$ or $\delta^{15} \mathrm{~N}-\mathrm{N}_{2}$ anomaly were not measured at stations 62,64 and 66 .

Figure 6. Raleigh relationships used to estimate $\varepsilon$ (slope) and initial $\delta^{15} \mathrm{~N}$-substrate ( $y$ intercept) assuming a closed system. (a) for $\mathrm{NO}_{3}^{-}$ reduction (Eq. 1 and text, Sect. 2.4), (b) for N-loss calculated from the substrate (DIN) consumption (Eq. 2 and text, Sect. 2.4) and (c) for $\mathrm{N}$-loss calculated from the $\delta^{15} \mathrm{~N}$ of biogenic $\mathrm{N}_{2}$ (Eq. 3 and text, Sect. 2.4). In (c), only samples with $\mathrm{O}_{2}$ concentrations less than $10 \mu \mathrm{M}$ and biogenic $\mathrm{N}_{2}$ values $>7.5 \mu \mathrm{M}$ were considered. Significant correlation coefficients at a 0.05 significance level are denoted by $*$.

$\mathrm{NO}_{2}^{-}$as an electron donor during $\mathrm{CO}_{2}$ fixation under anaerobic conditions (Strous et al., 2006).

Nitrite oxidation has its own unique set of isotope effects (Casciotti, 2009; Buchwald and Casciotti, 2010). Nitrite oxidation incurs an unusual inverse $\mathrm{N}$ isotope effect varying from $-13 \%$ for aerobic (Casciotti, 2009) to $-30 \%$ for anammox-mediated $\mathrm{NO}_{2}^{-}$oxidation (Brunner et al., 2013), resulting in lower $\delta^{15} \mathrm{~N}$ for $\mathrm{NO}_{2}^{-}$as it is oxidized to $\mathrm{NO}_{3}^{-}$, and increasing $\Delta \delta^{15} \mathrm{~N}$. Moreover, enzyme catalysis associated with $\mathrm{NO}_{2}^{-}$oxidation is readily reversible (Friedman et

al., 1986) also causing $\mathrm{O}$ isotope exchange between $\mathrm{NO}_{2}^{-}$ and water (Casciotti et al., 2007). O atom incorporation during both $\mathrm{NH}_{4}^{+}$and $\mathrm{NO}_{2}^{-}$oxidation have also been shown to occur with significant isotope effect, such that the $\delta^{18} \mathrm{O}$ of newly microbially produced $\mathrm{NO}_{3}^{-}$in the ocean range from -1.5 to $1.3 \%$ o (Buchwald and Casciotti, 2012).

Past studies have found $\mathrm{NO}_{2}^{-} \delta^{18} \mathrm{O}$ values in ODZ's in isotope equilibrium with water as a likely consequence of relatively long turnover time (e.g., Buchwald and Casciotti, 2013; Bourbonnais et al., 2015). O isotope exchange involves the protonated form, $\mathrm{HNO}_{2}$, but because of its high $\mathrm{pKa}$ as compared to $\mathrm{NO}_{3}^{-}$, this process can occur even at neutral to alkaline ocean $\mathrm{pH}$ on a timescale of 2 to 3 months at environmentally relevant temperatures (Casciotti et al., 2007). $\mathrm{NO}_{2}^{-} \delta^{18} \mathrm{O}$ isotopic composition at equilibrium with water is a function of the $\delta^{18} \mathrm{O}$ of water and temperature $(+14 \%$ o for seawater at $22{ }^{\circ} \mathrm{C}$ ) (Casciotti et al., 2007; Buchwald and Casciotti, 2013) and is independent of its $\delta^{15} \mathrm{~N}$ value such that plots of $\mathrm{NO}_{2}^{-} \delta^{18} \mathrm{O}$ vs. $\delta^{15} \mathrm{~N}$ usually have a slope of near zero. This is seen in our $\mathrm{NO}_{2}^{-}$data from offshore stations occupied during M90 (Fig. 5c). 
We observed, for the first time, a significant linear relationship for $\mathrm{NO}_{2}^{-} \delta^{18} \mathrm{O}$ vs. $\delta^{15} \mathrm{~N}$ at our inshore stations (slope $=0.64 \pm 0.07, r^{2}=0.59, p$ value $=3 \times 10^{-6}$ ) where $\mathrm{O}_{2}<10 \mu \mathrm{M}$ (Fig. 5b). Coupled $\delta^{15} \mathrm{~N}$ and $\delta^{18} \mathrm{O}$ effects for $\mathrm{NO}_{2}^{-}$have not been as well studied as $\mathrm{NO}_{3}^{-}$. Nevertheless, if $\mathrm{NO}_{2}^{-}$turnover was faster than equilibration time with water, $\mathrm{NO}_{3}^{-}$and $\mathrm{NO}_{2}^{-}$reduction whether as part of the denitrification, anammox or DNRA pathways, should also produce a positive relationship between $\mathrm{NO}_{2}^{-} \delta^{15} \mathrm{~N}$ and $\delta^{18} \mathrm{O}$. In contrast to our offshore stations (Fig. $5 \mathrm{c}$ ), this positive relationship thus demonstrates that the oxygen isotopic composition of $\mathrm{NO}_{2}^{-}$is not in equilibrium with water due to both rapid $\mathrm{NO}_{2}^{-}$turnover and the dominance of $\mathrm{NO}_{2}^{-}$reduction over oxidation in Peru coastal waters. Higher rates for aerobic $\mathrm{NH}_{4}^{+}$ and $\mathrm{NO}_{2}^{-}$oxidation, as well as anaerobic $\mathrm{NO}_{3}^{-}$reduction to $\mathrm{NO}_{2}^{-}$, and further reduction to $\mathrm{NH}_{4}^{+}$(DNRA) or $\mathrm{N}_{2}$, have been reported in shallow waters off Peru presumably due to increased coastal primary production and organic matter supply to the in-shore OMZ (e.g. Codispoti et al., 1986; Lam et al., 2011; Kalvelage et al., 2013). However, as our observations are restricted to anoxic waters, only high rates of N-loss could explain this more rapid $\mathrm{NO}_{2}^{-}$turnover.

In principal, we can estimate $\mathrm{NO}_{2}^{-}$turnover time from knowledge of rates for exchange with water and assumptions of the $\delta^{18} \mathrm{O}$ vs. $\delta^{15} \mathrm{~N}$ slope expected in the absence of exchange. Unfortunately, the slope of the relationship between $\mathrm{NO}_{2}^{-} \delta^{18} \mathrm{O}$ vs. $\delta^{15} \mathrm{~N}$ expected in the absence of equilibration with water is not yet known. An upper limit for turnover time for $\mathrm{NO}_{2}^{-}$can be estimated based on equilibration time as a function of in situ $\mathrm{pH}$ and temperature (Buchwald and Casciotti, 2013). During the M91 cruise in December, subsurface temperature was 13 to $15^{\circ} \mathrm{C}$ along our transect and corresponding $\mathrm{pH}$ was near 7.8 (Michelle Graco, unpublished data). Assuming the $\mathrm{NO}_{2}^{-}$pool is in steady-state, we estimated an equilibration time of up to $\sim 40$ days for $\mathrm{pH}$ near 7.8 (estimated from equation 1 and Fig. 2 in Buchwald and Casciotti, 2013). A turnover time of up to 40 days implies a flux of $\mathrm{N}$ through the $\mathrm{NO}_{2}^{-}$pool of at least $0.21 \mu \mathrm{Md}^{-1}$, as estimated from the maximum $\mathrm{NO}_{2}^{-}$concentration observed in this study divided by this estimated turnover time. Assuming steady-state, this range also approximates the rates of $\mathrm{NO}_{3}^{-}$reduction as well as $\mathrm{NO}_{2}^{-}$oxidation plus production of $\mathrm{N}_{2}$ from $\mathrm{NO}_{2}^{-}$. This estimated flux is consistent with measured high $\mathrm{NO}_{3}^{-}$reduction and $\mathrm{NO}_{2}^{-}$oxidation rates of up to $\sim 1 \mu \mathrm{M} \mathrm{d}^{-1}$ in Peru coastal waters $(<600 \mathrm{~m}$ depth, Kalvelage et al., 2013).

$\mathrm{NO}_{2}^{-}$oxidation is a chemoautotrophic process that requires a thermodynamically favorable electron acceptor such as $\mathrm{O}_{2}$. As mentioned above, $\mathrm{NO}_{2}^{-}$oxidation appears to occur in ODZ's at low or non-detectable $\mathrm{O}_{2}$ (e.g. Füssel et al., 2012) despite lack of knowledge of its thermodynamically favorable redox couple. The difference in $\delta^{15} \mathrm{~N}$ between $\mathrm{NO}_{2}^{-}$and $\mathrm{NO}_{3}^{-}\left(\Delta \delta^{15} \mathrm{~N}=\delta^{15} \mathrm{~N}-\mathrm{NO}_{3}^{-}-\delta^{15} \mathrm{~N}^{-\mathrm{NO}_{2}^{-}}\right.$
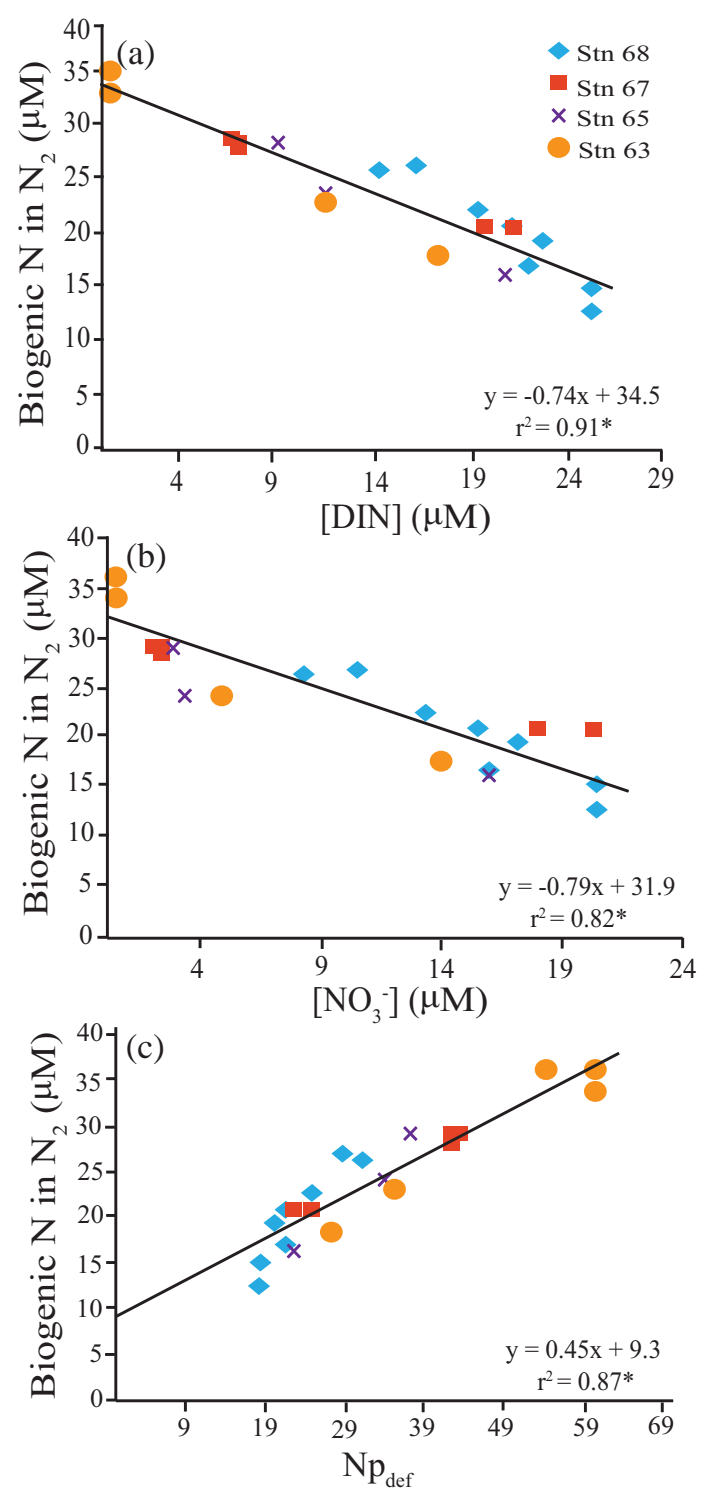

Figure 8. Cross-plots of biogenic $\mathrm{N}$ in $\mathrm{N}_{2}$ vs. DIN (a), $\mathrm{NO}_{3}^{-}$(b) and $\mathrm{Np}_{\text {def }}$ (c), see Eqs. (9-11) in text). All plots have the overall linear regression overlaid. All the points are restricted to $\mathrm{O}_{2}$ concentrations less than $10 \mu \mathrm{M}$. Biogenic $\mathrm{N}_{2}$ was not measured for stations 62, 64 and 66. Significant correlation coefficients at a 0.05 significance level are denoted by $*$.

see Sect. 3.3) is further evidence for the presence of $\mathrm{NO}_{2}^{-}$ oxidation in the ODZ (e.g. Casciotti et al., 2013). At steadystate, and in the absence of $\mathrm{NO}_{2}^{-}$oxidation, $\Delta \delta^{15} \mathrm{~N}$ should be no more than the $\varepsilon$ for $\mathrm{NO}_{3}^{-}$reduction (20 to $30 \%$ ) minus the $\varepsilon$ for $\mathrm{NO}_{2}^{-}$reduction by denitrifying or anammox bacteria (12-16\%; Bryan et al., 1983; Brunner et al., 2013; Bourbonnais et al., 2015) or 8-18\%o . Our results range from $15-40 \%$ and average $29.8 \%$ or for samples with $\mathrm{O}_{2}$ concentrations $<10 \mu \mathrm{M}$. 
The inverse kinetic isotope effect associated with $\mathrm{NO}_{2}^{-}$oxidation is likely responsible for these high $\Delta \delta^{15} \mathrm{~N}$ values (e.g. Casciotti and Buchwald, 2012; Casciotti et al., 2013). Taking all isotope effects into account, the following equation can be derived to estimate $\Delta \delta^{15} \mathrm{~N}$ at steady-state:

$$
\begin{aligned}
\Delta \delta^{15} \mathrm{~N}(\text { steady state }) & =\varepsilon_{\mathrm{NO}_{3}-\mathrm{red}}-(1-\gamma) \\
& \times \varepsilon_{\mathrm{NO}_{2}-\mathrm{red}}-\gamma \times \varepsilon_{\mathrm{NO}_{2}-\text { oxid }},
\end{aligned}
$$

where $\gamma$ is the fraction of $\mathrm{NO}_{2}^{-}$oxidized back to $\mathrm{NO}_{3}^{-}$. Highest values (over $30 \%$ ) are found between 50 and $100 \mathrm{~m}$, implying greater importance for $\mathrm{NO}_{2}^{-}$oxidation in deeper waters.

Given that $\varepsilon_{\mathrm{NO}_{2}-\text { oxid }}$ has been reported to be $-13 \%$ ofor aerobic $\mathrm{NO}_{2}^{-}$oxidation and using the literature ranges for

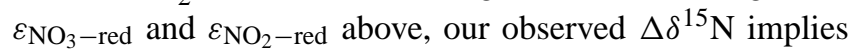
that up to $100 \%$ of $\mathrm{NO}_{2}^{-}$produced by $\mathrm{NO}_{3}^{-}$reduction could be oxidized back to $\mathrm{NO}_{3}^{-}$. This estimate is higher than ratios of $\mathrm{NO}_{2}^{-}$oxidation $/ \mathrm{NO}_{3}^{-}$reduction of up to $54 \%$ for the Peruvian coastal ODZ derived from direct rate measurements (Lam et al., 2009; Kalvelage et al., 2013), and should thus be considered as an upper limit. Alternatively, $\mathrm{NO}_{2}^{-}$oxidation also occurs as part of the overall metabolism of anammox bacteria (Strous et al., 2006) which can be the dominant $\mathrm{N}_{2}$ producers in the Peru ODZ (Kalvelage et al., 2013). A large inverse kinetic $\varepsilon$ for $\mathrm{NO}_{2}^{-}$oxidation of $\sim-30 \%$ o has been observed for anammox bacteria in culture (Brunner et al., 2013). If this is the sole pathway for $\mathrm{NO}_{2}^{-}$oxidation, our data suggest $\mathrm{NO}_{2}^{-}$oxidation up to only $\sim 80 \%$ of total $\mathrm{NO}_{3}^{-}$reduction. However, anammox bacteria only oxidize a minor fraction of $\mathrm{NO}_{2}^{-}$to $\mathrm{NO}_{3}^{-}$in culture. At the same time, estimates of $\mathrm{NO}_{2}^{-}$oxidation ( 8.48 to $928 \mathrm{nM} \mathrm{d}^{-1}$ ) are significantly higher than $\mathrm{N}$-loss rates by anammox (2.84 to $227 \mathrm{nmol} \mathrm{N} \mathrm{L}^{-1} \mathrm{~d}^{-1}$ ) on the Peruvian shelf (Kalvelage et al., 2013), clearly indicating non-anammox related nitrite oxidation.

The deviations from a $1: 1$ relationship for $\mathrm{NO}_{3}^{-} \delta^{18} \mathrm{O}$ and $\delta^{15} \mathrm{~N}$ can also be indicative of $\mathrm{NO}_{2}^{-}$oxidation. During $\mathrm{NO}_{3}^{-}$uptake or dissimilative $\mathrm{NO}_{3}^{-}$reduction, $\mathrm{NO}_{3}^{-} \delta^{15} \mathrm{~N}$ and $\delta^{18} \mathrm{O}$ increase equally with a ratio of $1: 1$ (Granger et al., 2004, 2008). We observed a slope of about 0.86 (Fig. 5a) for the $\mathrm{NO}_{3}^{-} \delta^{18} \mathrm{O}$ vs. $\delta^{15} \mathrm{~N}$ relationship in the in-shore Peru ODZ, similar to recent off-shore observations (Bourbonnais et al., 2015). Prior reports of deviations toward higher values for the slope were indicative of addition of newly nitrified $\mathrm{NO}_{3}^{-}$from a relatively low $\delta^{15} \mathrm{~N}$ source (e.g. see Sigman et al., 2005; Bourbonnais et al., 2009). Our observed deviation toward slopes $<1$ can instead be explained by the addition of newly nitrified $\mathrm{NO}_{3}^{-}$with a lower $\delta^{18} \mathrm{O}-\mathrm{NO}_{3}^{-}$, mostly derived from water (Andersson and Hooper, 1983), relative to the high ambient $\delta^{18} \mathrm{O}-\mathrm{NO}_{3}^{-}$values. In fact, a slope for $\delta^{18} \mathrm{O}: \delta^{15} \mathrm{~N}$ of either greater or less than 1 can be observed, depending on initial environmental $\mathrm{NO}_{3}^{-}$isotopic composition relative to any in situ sources (Casciotti et al., 2013). Casciotti and Buchwald (2012) showed model results where $\mathrm{NO}_{2}^{-}$oxidation generally produces a slope $<1$ for the $\mathrm{NO}_{3}^{-} \delta^{18} \mathrm{O}$ vs. $\delta^{15} \mathrm{~N}$ relationship, when the $\mathrm{NO}_{3}^{-} \delta^{15} \mathrm{~N}$ and $\delta^{18} \mathrm{O}$ are higher than $\sim 15 \%$ o as observed in Casciotti et al. (2013) and Bourbonnais et al. (2015).

\subsection{Isotope effects for $\mathrm{N}$-loss}

As described above, the Rayleigh fractionation equations (Eqs. 1 to 6) are used here to estimate $\varepsilon$ values (Mariotti et al., 1981; Altabet, 2005) and examine the significance of calculations using (a) different approaches for calculating $f$ (Eqs. 7 and 14), (b) changes in the $\delta^{15} \mathrm{~N}$ of substrate (DIN) vs. changes in the $\delta^{15} \mathrm{~N}$ of product, and (c) closed vs. open system equations. This approach provides redundancy in our estimates of $\varepsilon$ and tests implied assumptions including $\mathrm{N}$ and ${ }^{15} \mathrm{~N}$ balance between $\mathrm{NO}_{3}^{-}$or DIN loss and the accumulation of biogenic $\mathrm{N}_{2}$.

Linear regression coefficients for $\varepsilon$ calculated using the different approaches presented in Sect. 2.4 are listed in Tables 1 and 2. For example, Rayleigh closed system plots for $\delta^{15} \mathrm{~N}^{-\mathrm{NO}_{3}^{-}}, \delta^{15} \mathrm{~N}-\mathrm{DIN}$, or $\delta^{15} \mathrm{~N}$ biogenic $\mathrm{N}_{2}$ as a function of $f_{2 \mathrm{bioN}_{2}}$ are shown in Fig. 6. Surprisingly, $\varepsilon$ values estimated from the slope of these relationships are not sensitive to choice of method for calculating $f$ despite the lack of $1: 1$ correspondence between different bases $\left(\mathrm{Np}_{\text {expected }}\right.$, biogenic $\mathrm{N}_{2}$, or $\left.\left[\mathrm{NO}_{3}^{-}\right] /\left[\mathrm{NO}_{3}^{-}\right]_{\max }\right)$. In the case of $\varepsilon$ calculated from changes in $\delta^{15} \mathrm{~N}$-DIN, $\varepsilon$ ranged narrowly with choice of $f$ from 6.3 to $7.4 \%$ with standard errors on the slope of $<0.6 \%$ o (Table 1). As there was no significant difference between bases for calculating $f$, it appears that all three of our approaches are valid for this purpose.

However, $\varepsilon$ for $\mathrm{N}$-loss (closed system) does vary significantly between calculations using changes in $\delta^{15} \mathrm{~N}_{-} \mathrm{NO}_{3}^{-}$, $\delta^{15} \mathrm{~N}$-DIN, or $\delta^{15} \mathrm{~N}$ biogenic $\mathrm{N}_{2} . \varepsilon$ is largest for changes in $\delta^{15} \mathrm{~N}^{-\mathrm{NO}_{3}^{-}}(\sim 14 \%)$ and smallest for changes in $\delta^{15} \mathrm{~N}$ DIN $(\sim 7 \% \circ)$. $\varepsilon$ based on $\delta^{15} \mathrm{~N}$ biogenic $\mathrm{N}_{2}$ is intermediate $\left(\sim 11 \%\right.$ ). The latter two, using DIN or biogenic $\mathrm{N}_{2}$ as the basis to calculate $\varepsilon$, are more representative of $\mathrm{N}$-loss. Calculations based on changes in $\delta^{15} \mathrm{~N}_{-} \mathrm{NO}_{3}^{-}$are affected by $\mathrm{NO}_{2}^{-}$accumulation and isotope effects of $\mathrm{NO}_{2}^{-}$oxidation (see above). The $4 \%$ difference in $\varepsilon$ calculated from changes in $\delta^{15} \mathrm{~N}$ of biogenic $\mathrm{N}_{2}$ vs. $\delta^{15} \mathrm{~N}$ of DIN may arise from the contribution of $\mathrm{NH}_{4}^{+}$derived from organic matter to biogenic $\mathrm{N}_{2}$ via the anammox process. Supporting this hypothesis, $\mathrm{NH}_{4}^{+}$accumulation (5.3-7.5 $\left.\mu \mathrm{M}\right)$ associated with a relatively low $\delta^{15} \mathrm{~N}^{-\mathrm{NH}_{4}^{+}}$of 3.8 to $6.1 \%$ o was observed at 125 and $200 \mathrm{~m}$ bottom water depths at shallow stations located in the studied area $\left(\sim 12.3^{\circ} \mathrm{S}\right.$ and $\left.77.3^{\circ} \mathrm{W}\right)$ in January 2013 (unpublished results). A contribution of $\mathrm{NH}_{4}^{+}$from organic material and consumption by anammox could therefore supply comparatively lower $\delta^{15} \mathrm{~N}$ to the biogenic $\mathrm{N}_{2}$ pool, increasing $\varepsilon$. 
Table 2. $\varepsilon$ for $\mathrm{NO}_{3}^{-}$reduction, and net $\mathrm{N}$ loss estimated from both DIN consumption and produced biogenic $\mathrm{N}_{2}$ using Rayleigh open system equations (Eqs. 4-6). Results are calculated for $f$ based on either $\mathrm{Np}_{\text {expected }}$ (Eqs. 7-9), biogenic $\mathrm{N}_{2}$ (Eqs. 12-14), and measured substrate divided by maximum (upwelled) substrate concentrations (see text, Sect. 2.4). The standard error of the slope $(\varepsilon)$ is shown.

\begin{tabular}{|c|c|c|c|c|}
\hline & Basis for $f$ & $\varepsilon$ & $y$ intercept & $r^{2}$ \\
\hline \multirow[t]{4}{*}{$\delta^{15} \mathrm{~N}^{-\mathrm{NO}_{3}^{-}}$} & $\mathrm{Np}_{\text {expected }}$ & $63.0 \pm 4.5$ & -18.42 & 0.86 \\
\hline & $\mathrm{N}_{2}$ Biogenic & $66.30 \pm 6.2$ & -21.92 & 0.87 \\
\hline & {$\left[\mathrm{NO}_{3}^{-}\right] /\left[\mathrm{NO}_{3}^{-}\right]_{\max }$} & $38.9 \pm 2.7$ & 6.19 & 0.87 \\
\hline & Npexpected & $17.4 \pm 1.2$ & 3.26 & 0.88 \\
\hline \multirow[t]{2}{*}{$\delta^{15} \mathrm{~N}-\mathrm{DIN}$} & $\mathrm{N}_{2}$ Biogenic & $20.0 \pm 1.8$ & 1.72 & 0.89 \\
\hline & DIN / DIN ${ }_{\max }$ & $13.2 \pm 0.9$ & 8.45 & 0.91 \\
\hline \multirow[t]{2}{*}{$\delta^{15} \mathrm{~N}$-Biogenic $\mathrm{N}_{2}$} & $N p_{\text {expected }}$ & $12.3 \pm 1.9$ & 1.94 & 0.67 \\
\hline & $\mathrm{N}_{2}$ Biogenic & $14.15 \pm 2.1$ & 2.25 & 0.68 \\
\hline
\end{tabular}

The different approaches for estimating the $\varepsilon$ for N-loss can also be evaluated by examining the initial substrate $\delta^{15} \mathrm{~N}$ predicted where $f=1$ for each set of regressions. In the case of changes in $\delta^{15} \mathrm{~N}$-DIN and using $\mathrm{Np}_{\text {expected }}$ or biogenic $\mathrm{N}_{2}$ as bases for $f$, realistic values are found consistent with the source of upwelled waters of 6 to $7 \%$ (Table 1; also see Ryabenko et al., 2012). For regressions based on changes in $\delta^{15} \mathrm{~N}$-biogenic $\mathrm{N}_{2}$, initial $\delta^{15} \mathrm{~N}$ values are somewhat lower ( $\sim 3 \%$ ), possibly due to a source from organic $\mathrm{N}$ decomposition.

Estimates of $\varepsilon$ using open-system equations are generally much higher than for closed system equations particularly for changes in $\delta^{15} \mathrm{~N}^{-\mathrm{NO}_{3}^{-}}$with unrealistically high values (39$63 \%$; Table 2). However, values for both closed and open systems tended to converge for estimates based on changes in $\delta^{15} \mathrm{~N}$-DIN or $\delta^{15} \mathrm{~N}$-biogenic $\mathrm{N}_{2}$ with the latter having no significant difference. Estimates of substrate initial $\delta^{15} \mathrm{~N}$ using the open system equations range widely and do not consistently reflect realistic values (Table 2 ).

Closed system estimates of $\varepsilon$ are likely more reliable in our setting because of low likelihood of mixing between water masses of contrasting characteristics on the shelf. Temperature and salinity in the ODZ at our stations narrowly ranged from 13.5 to $15^{\circ} \mathrm{C}$ and 34.88 to 34.98 (Fig. 2), similar to $T / S$ signatures from offshore source waters (Bourbonnais et al., 2015), and suggestive of a single water mass. Accordingly, as in Bourbonnais et al. (2015), we view the closed system equations as most reliable with a value of $\sim 6.5 \%$ o for $\varepsilon$ based on changes in $\delta^{15} \mathrm{~N}$ DIN as the likely best estimate. However, given the overlap with the results of open system equations for changes in $\delta^{15} \mathrm{~N}$ of biogenic $\mathrm{N}_{2}$, an upper bound of $\sim 11 \%$ appears appropriate. This range in $\varepsilon$ for $\mathrm{N}$-loss falls below the results of Bourbonnais et al. (2015) for a near-coastal eddy in the same region and time period $(\sim 14 \%$ o) and is much less than the canonical range of 20 to $30 \%$ (Brandes et al., 1998; Voss et al., 2001; Granger et al., 2008). As discussed in Bourbonnais et al. (2015), a lower overall $\varepsilon$ for net $\mathrm{N}$-loss could help resolve any imbalance in the oceanic N-budget, by decreasing the ratio of sedimentary and water-column N-loss necessary to account for the observed $\delta^{15} \mathrm{~N}$ of mean ocean $\mathrm{NO}_{3}^{-}$.

There are several reasonable explanations for these relatively low $\varepsilon$ values in coastal waters. These include higher microbial growth rates associated with higher productivity, which would shift biochemical rate limitation away from enzyme reactions to membrane transport with low fractionation potential (e.g. Wada and Hattori, 1978). Another is greater influence from benthic $\mathrm{N}$ cycling processes in our relatively shallow inshore system as compared to deeper waters. Sediment $\mathrm{N}$-loss has been shown to incur low $\varepsilon$ due to, in analogous fashion to the affect of microbial growth rate, dominance of substrate transport limitation through the sediment (Brandes and Devol, 1997). This possibility will be explored further in the next section. Unlikely explanations for our relatively low $\varepsilon$ values for $\mathrm{N}$-loss include the effects of decreasing $\mathrm{NO}_{3}^{-}$concentration (Kritee et al., 2012) and contributions from organic $\mathrm{N}$ via anammox to biogenic $\mathrm{N}_{2}$. Lack of curvature in the Rayleigh plots demonstrates a lack of dependence of substrate concentration (Fig. 6a, b) as the range in $f$ corresponds to a large range in $\mathrm{NO}_{3}^{-}$or DIN concentrations. The possible effects of contributions from organic $\mathrm{N}$ to biogenic $\mathrm{N}_{2}$ has already been taken into account in calculations based on changes in the $\delta^{15} \mathrm{~N}$ of biogenic $\mathrm{N}_{2}$, as discussed above.

\subsection{Using $\varepsilon$ values for estimating sediment $\mathrm{N}$-loss}

The low $\varepsilon$ value we observe for water column N-loss at our inshore stations may be explained by contributions from sediment N-loss (e.g. see Sigman et al., 2003). If so, observed $\varepsilon$ for N-loss in the water-column should be the weighted average of the actual $\varepsilon$ values for N-loss in the water column and sediments:

$\varepsilon_{\mathrm{obs}}=\varepsilon_{\mathrm{wc}} \times\left(1-P_{\mathrm{sed}}\right)+\varepsilon_{\mathrm{sed}} \times P_{\text {sed }}$,

where $\varepsilon_{\mathrm{wc}}$ and $\varepsilon_{\text {sed }}$ are the isotope effect of water column and sediments and $P_{\text {sed }}$ is the proportion of water column and sedimentary $\mathrm{N}$-loss, respectively. We take $6.8 \pm 0.5 \%$ as the value for $\varepsilon_{\text {obs }}$ (Fig. 6, Table 1), a value of $13.8 \pm 1.3 \%$ o for $\varepsilon_{\mathrm{wc}}$ as estimated for offshore waters by Bourbonnais et al. (2015), and a $\varepsilon_{\text {sed }}$ of $1.5 \%$ as in Sigman et al. (2003). From these numbers, we estimated that the proportion of $\mathrm{N}$ loss due to sedimentary N-loss could be up to $\sim 60 \%$ (48 to $64 \%$ ) at our coastal stations, which is in the same range than previously reported for other marine coastal environments, e.g. Saanich Inlet (also up to $60 \%$; Bourbonnais et al., 2013). Our estimate is higher than the $25 \%$ of benthic vs. total Nloss from a reaction-diffusion model and direct flux measurements for the same coastal region off Peru (Kalvelage et al., 2013). However, our comparison to direct measurements of fluxes should be considered tentative as they are made at single locations over relatively short time periods are thus subject to considerable spatial and temporal heterogeneity. 


\section{Conclusions}

The inshore Peru ODZ is distinguished from offshore by its high productivity as a consequence of coastal upwelling as well as possible greater influence from benthic processes. To examine impact on $\mathrm{N}$-loss processes and their isotope effects, we investigated the dynamics of $\mathrm{N}$ and $\mathrm{O}$ isotope of $\mathrm{NO}_{2}^{-}$and $\mathrm{NO}_{3}^{-}$at six coastal stations off Peru.

We found that $\mathrm{N}$-loss representing the net effect of partial denitrification, anammox, and nitrification produced, in sum, large variations in isotopic composition. $\mathrm{NO}_{2}^{-} \delta^{15} \mathrm{~N}$ ranged from -20 to $10 \%$ and $\mathrm{NO}_{3}^{-} \delta^{15} \mathrm{~N}$ ranged from 10 to $50 \%$. Generally, $\mathrm{NO}_{3}^{-}$and $\mathrm{NO}_{2}^{-}$isotope values varied inversely with their concentrations as expected for Rayleigh-like fractionation effects. Isotope values were usually higher in low$\mathrm{O}_{2}$ near bottom waters where $\mathrm{N}$ species concentrations were also relatively low.

We observed, for the first time, a positive linear relationship between $\mathrm{NO}_{2}^{-} \delta^{15} \mathrm{~N}$ and $\delta^{18} \mathrm{O}$ at our inshore stations. In offshore ODZ waters, such a relationship has never previously been observed as $\mathrm{NO}_{2}^{-} \delta^{18} \mathrm{O}$ reflected equilibration with water in these regions (Buchwald and Casciotti, 2013). Our results suggest a turnover time for $\mathrm{NO}_{2}^{-}$faster than the equilibration time with water and the effect of $\mathrm{NO}_{2}^{-}$oxidation over $\mathrm{NO}_{2}^{-}$reduction in these highly productive coastal waters. We estimated an $\mathrm{NO}_{2}^{-}$turnover time of up to $\sim 40$ days from our data.

The difference in $\delta^{15} \mathrm{~N}$ between $\mathrm{NO}_{3}^{-}$and $\mathrm{NO}_{2}^{-}\left(\Delta \delta^{15} \mathrm{~N}\right)$ was high, reaching up to $40 \%$ o in deeper waters, and was greater than expected from $\mathrm{NO}_{3}^{-}$and $\mathrm{NO}_{2}^{-}$reduction only. The influence of $\mathrm{NO}_{2}^{-}$oxidation is consistent with this observation due to its inverse fractionation effect (Casciotti, 2009). Additional evidence for $\mathrm{NO}_{2}^{-}$oxidation is found in the relationship between $\mathrm{NO}_{3}^{-} \delta^{15} \mathrm{~N}$ and $\delta^{18} \mathrm{O} . \mathrm{NO}_{3}^{-}$reduction alone is expected to produce a $1: 1$ relationship (Granger et al., 2008). While we observed a linear relationship between $\mathrm{NO}_{3}^{-} \delta^{15} \mathrm{~N}$ and $\delta^{18} \mathrm{O}$, the slope of 0.86 is indicative of simultaneous addition of $\mathrm{NO}_{3}^{-}$with relatively low $\delta^{18} \mathrm{O}$, also consistent with a role for $\mathrm{NO}_{2}^{-}$oxidation at our coastal sites. However, a favorable thermodynamic couple for $\mathrm{NO}_{2}^{-}$ oxidation in the absence of $\mathrm{O}_{2}$ in these waters remains unknown.

A number of different approaches for estimating $\varepsilon$ for $\mathrm{N}$ loss were compared including choice of $\mathrm{N}$ form for changes in $\delta^{15} \mathrm{~N}\left(\mathrm{NO}_{3}^{-}\right.$, DIN, or biogenic $\left.\mathrm{N}_{2}\right)$, closed vs. open system Rayleigh equations, and the basis for calculating the denominator in $f$ (Npexpected, biogenic $\mathrm{N}_{2}$, or maximum $\mathrm{NO}_{3}^{-}$). For the latter, there was little difference in estimated $\varepsilon$ despite discrepancies between the removal of $\mathrm{NO}_{3}^{-}$and appearance of $\mathrm{N}_{2}$ estimated from them. Observation of a single water mass $(T-S$ plot $)$ in our coastal region as well as more realistic ranges for derived $\varepsilon$ and initial $\delta^{15} \mathrm{~N}$ indicated that closed system assumptions were more realistic. Using closed system equations, relatively low $\varepsilon$ values were calculated; $\sim 7 \%$ ofor changes in the $\delta^{15} \mathrm{~N}$ of DIN and $\sim 11 \%$ ofor changes in the $\delta^{15} \mathrm{~N}$ of biogenic $\mathrm{N}_{2}$. As in Bourbonnais et al. (2015), $\varepsilon$ calculated from changes in the $\delta^{15} \mathrm{~N}$ of $\mathrm{NO}_{3}^{-}$alone was not representative of the $\varepsilon$ for overall $\mathrm{N}$ loss in consideration of the build up of $\mathrm{NO}_{2}^{-}$with distinct $\delta^{15} \mathrm{~N}$. These estimates for $\varepsilon$ for net $\mathrm{N}$-loss are lower than recently reported for a nearby offshore eddy with intense $\mathrm{N}$ loss ( $\sim 14 \%$; Bourbonnais et al., 2015). This lower $\varepsilon$ may be attributed to the influence of sedimentary N-loss on the Peruvian shelf (e.g., Bohlen et al., 2011) with a highly suppressed $\varepsilon$ on the overlying water column at our shallow stations. Given this assumption, we estimate that sedimentary $\mathrm{N}$-loss (by both denitrification and anammox) could account for up to $60 \%$ of the total N-loss in in shore Peru ODZ waters.

Our results further support geographical variations in the $\varepsilon$ of N-loss in ODZs, possibly related to the effects of varying primary productivity and microbial growth rates on the expression of $\varepsilon$ and partitioning between water-column and sedimentary denitrification. These variations need to be considered in future global isotopic $\mathrm{N}$ budget (e.g. see Brandes and Devol, 2002), potentially bringing the global $\mathrm{N}$ budget more in balance. This is further supported by the relatively lower $\varepsilon$ for $\mathrm{N}$-loss of $\sim 14 \%$ o recently observed offshore in the ETSP ODZ by Bourbonnais et al. (2015). A lower watercolumn $\varepsilon$ for $\mathrm{N}$-loss also decreases the fraction of sedimentary denitrification needed to balance the global isotopic $\mathrm{N}$ budget (Brandes and Devol, 2002; Altabet, 2007).

Acknowledgements. Data for this paper are available on the Data Management Portal for Kiel Marine Sciences hosted at GEOMAR: https://portal.geomar.de/, or upon request to the corresponding author. This research was supported by the Deutsche Forschungsgemeinschaft- project SFB-754 (Climate-Biogeochemistry Interactions in the Tropical Ocean: www.sfb754.de), SOPRAN II (grant \# FKZ 03F0611A; Surface Ocean Processes in the Anthropocene: http://sopran.pangaea.de), the Nitrogen Isotope and $\mathrm{N}_{2} / \mathrm{Ar}$ Biogeochemistry of the Peru Suboxic Zone project (National Science Foundation award OCE0851092), the University of Massachusetts Intercampus Marine Science graduate program support to Happy $\mathrm{Hu}$ and a NSERC Postdoctoral Fellowship to Annie Bourbonnais We would like to thank the captain and crew of R/V Meteor during the M91 cruise and Daniel Kiefhaber, Avi Bernales and Violeta Leon for their help during sampling and/or sample analysis. We thank the authorities of Peru for the permission to work in their territorial waters.

Edited by: C. Robinson

\section{References}

Alkhatib, M., Lehmann, M. F., and del Giorgio, P. A.: The nitrogen isotope effect of benthic remineralization-nitrificationdenitrification coupling in an estuarine environment, Biogeosciences, 9, 1633-1646, doi:10.5194/bg-9-1633-2012, 2012. 
Altabet, M. A.: Isotopic tracers of the marine nitrogen cycle: present and past, in The handbook of environmental chemistry, vol. 2, edited by: Hutzinger, O., Springer-Verlag, Berlin, Heidelberg, 251-293, 2005.

Altabet, M. A.: Constraints on oceanic $\mathrm{N}$ balance/imbalance from sedimentary ${ }^{15} \mathrm{~N}$ records, Biogeosciences, 4, 75-86, doi:10.5194/bg-4-75-2007, 2007.

Andersson, K. K. and Hooper, A. B.: $\mathrm{O}_{2}$ and $\mathrm{H}_{2} \mathrm{O}$ are each the source of one $\mathrm{O}$ in $\mathrm{NO}_{2}^{-}$Produced from $\mathrm{NH}_{3}$ by Nitrosomonas: ${ }^{15}$ N-NMR evidence, FEBS Lett., 164, 236-240, 1983.

Babbin, A. R., Keil, R. G. Devol, A. H., and Ward, B. B.: Organic Matter Stoichiometry, Flux, and Oxygen Control Nitrogen Loss in the Ocean, Science, 344, 406-408, 2014.

Bohlen, L., Dale, A. W., Sommer, S., Mosch, T., Hensen, C., Noffke, A., Scholz, F., and Wallmann, K.: Benthic nitrogen cycling traversing the Peruvian oxygen minimum zone, Geochim. Cosmochim. Ac., 75, 6094-6111, 2011.

Bourbonnais, A., Lehmann, M. F. Waniek, J. J., and Schulz-Bull, D. E.: Nitrate Isotope Anomalies Reflect $\mathrm{N}_{2}$ Fixation in the Azores Front Region (subtropical NE Atlantic), J. Geophys. Res.-Oceans, 114, C03003, doi:10.1029/2007JC004617, 2009.

Bourbonnais, A., Lehmann, M. F., Hamme, R. C., Manning, C. C, and Kim Juniper, S.: Nitrate elimination and regeneration as evidenced by dissolved inorganic nitrogen isotopes in Saanich Inlet, a seasonally anoxic fjord, Mar. Chem., 157, 194-207, 2013.

Bourbonnais, A., Altabet, M. A., Charoenpong, C. N., Larkum, J., Hu, H., Bange, H. W., and Stramma, L.: N-loss isotope effects in the Peru oxygen minimum zone studied using a mesoscale eddy as a natural tracer experiment, Global Biogeochem. Cy., 29, 793811, doi:10.1002/2014GB005001, 2015.

Brandes, J. A. and Devol, A. H. Isotopic Fractionation of Oxygen and Nitrogen in Coastal Marine Sediments, Geochim. Cosmochim. Ac., 61, 1793-1801, 1997.

Brandes, J. A. and Devol, A. H.: A global marine-fixed nitrogen isotopic budget: Implications for Holocene nitrogen cycling, Global Biogeochem. Cy., 16, 67-1-67-14, 2002.

Brandes J. A., Devol, A. H., Yoshinari, T., Jayakumar D. A., and Naqvi, S. W. A.: Isotopic composition of nitrate in the central Arabian Sea and eastern tropical North Pacific: A tracer for mixing and nitrogen cycles, Limnol. Oceanogr., 43, 1680-1689, 1998.

Brunner, B. Contreras, S., Lehmann, M. F., Matantseva, O., Rollog, M., Kalvelage, T., Klockgether, G., Lavik, G., Jetten, M. S. M., Kartal, B., and Kuypers, M. M. M: Nitrogen isotope effects induced by anammox bacteria, P. Natl. Acad. Sci. USA, 110, 18994-18999, 2013.

Bryant, J. P., Chapin, F. S., and Klein, D. R. Carbon uutrient balance of boreal plants in relation to vertebrate herbivory, Oikos, 40, 357-68, 1983.

Buchwald, C. and Casciotti, K. L.: Oxygen isotopic fractionation and exchange during bacterial nitrite oxidation, Limnol. Oceanogr., 55, 1064-1074, 2010.

Buchwald, C. and Casciotti, K. L.: Isotopic ratios of nitrite as tracers of the sources and age of oceanic nitrite, Nat. Geosci., 6, 308313, 2013.

Casciotti, K. L.: Inverse kinetic isotope fractionation during bacterial nitrite oxidation, Geochim. Cosmochim. Ac., 73, 2061-2076, 2009.
Casciotti, K. L. and Buchwald, C.: Insights on the marine microbial nitrogen cycle from isotopic approaches to nitrification, Front. Microbiol., 3, 356, doi:10.3389/fmicb.2012.00356, 2012.

Casciotti, K. L. and McIlvin, M. R.: Isotopic analyses of nitrate and nitrite from reference mixtures and application to eastern tropical North Pacific waters, Mar. Chem., 107, 184-201, 2007.

Casciotti, K. L. Sigman, D. M., Hastings, M. G., Böhlke, J. K., and Hilkert, A.: Measurement of the oxygen isotopic composition of nitrate in seawater and freshwater using the denitrifier method, Anal. Chem., 74, 4905-4912, 2002.

Casciotti, K. L., Böhlke, J. K., McIlvin, M. R.,Mroczkowski, S. J., and Hannon, J. E.: Oxygen isotopes in nitrite: analysis, calibration, and equilibration, Anal. Chem., 79, 2427-2436, 2007.

Casciotti, K. L., McIlvin, M., and Buchwald, C.: Oxygen Isotopic Exchange and Fractionation during Bacterial Ammonia Oxidation, Limnol. Oceanogr., 55, 753-762, 2010.

Casciotti, K. L., Buchwald, C., and McIlvin, M.: Implications of nitrate and nitrite isotopic measurements for the mechanisms of nitrogen cycling in the Peru oxygen deficient zone, Deep-Sea Res. Pt. I, 80, 78-93, 2013.

Chang, B. X., Devol, A. H., and Emerson, S. R.: Denitrification and the nitrogen gas excess in the eastern tropical South Pacific oxygen deficient zone, Deep-Sea Res. Pt. I, 57, 1092-1101, 2010.

Cline, J. D. and Kaplan, I. R.: Isotopic Fractionation of Dissolved Nitrate during Denitrification in the Eastern Tropical North Pacific Ocean, Mar. Chem., 3, 271-299, 1975.

Charoenpong, C. N., Bristow, L. A., and Altabet, M. A.: A continuous flow isotope ratio mass spectrometry method for high precision determination of dissolved gas ratios and isotopic composition, Limnol. Oceanogr.-Meth., 12, 323-337, 2014.

Codispoti, L. A.: An oceanic fixed nitrogen sink exceeding $400 \mathrm{Tg} \mathrm{N} \mathrm{a}^{-1}$ vs the concept of homeostasis in the fixed-nitrogen inventory, Biogeosciences, 4, 233-253, doi:10.5194/bg-4-2332007, 2007.

Codispoti, L. A. and Christensen, J. P.: Nitrification, denitrification and nitrous oxide cycling in the eastern tropical South Pacific ocean, Mar. Chem., 16, 277-300, 1985.

Codispoti, L. A., Friederich, G. E., Packard, T. T., Glover, H. E., Kelly, P. J., Spinrad, R. W., and Barber, R. T.: High Nitrite Levels off Northern Peru: A Signal of Instability in the Marine Denitrification Rate, Science, 233, 1200-1202, 1986.

Dalsgaard, T., Thamdrup, B., Farías, L., and Revsbech, N. P.: Anammox and denitrification in the oxygen minimum zone of the eastern South Pacific, Limnol. Oceanogr., 57, 1331-1346, 2012.

Dalsgaard, T., Stewart, F. J., Thamdrup, B., Brabandere, L. D., Revsbech, P., and Ulloa, O.: Oxygen at Nanomolar Levels Reversibly Suppresses Process Rates and Gene Expression in Anammox and Denitrification in the Oxygen, mBio, 5, e0196614, doi:10.1128/mBio.01966-14, 2014.

Deutsch, C., Sarmiento, J. L., Sigman, D. M., Gruber, N., and Dunne, J. P.: Spatial coupling of nitrogen inputs and losses in the ocean, Nature, 445, 163-167, 2007.

DeVries, T., Deutsch, C., Primeau, F., Chang, B., and Devol, A.: Global rates of water-column denitrification derived from nitrogen gas measurements, Nature, 5, 547-550, 2012.

Dore, J. E. and Karl, D. M.: Nitrification in the Euphotic Zone as a Source for Nitrite, Nitrate, and Nitrous Oxide at Station ALOHA, Limnol. Oceanogr., 41, 1619-1628, 1996. 
Eugster, O. and Gruber, N.: A probabilistic estimate of global marine $\mathrm{N}$-fixation and denitrification, Global Biogeochem. Cy., 26, $1-15,2012$.

Friedman, S. H., Massefski, W., and Hollocher, T. C.: Catalysis of intermolecular oxygen atom transfer by nitrite dehydrogenase of Nitrobacter agilis, J. Biol. Chem., 261, 10538-10543, 1986.

Füssel, J., Lam, P., Lavik, G., Jensen, M. M., Holtappels, M., Günter, M., and Kuypers, M. M. M.: Nitrite oxidation in the Namibian oxygen minimum zone, ISME J., 6, 1200-1209, 2012.

Granger, J. and Sigman, D. M.: Removal of nitrite with sulfamic acid for nitrate $\mathrm{N}$ and $\mathrm{O}$ isotope analysis with the denitrifier method, Rapid Commun. Mass Sp., 23, 3753-3762, 2009.

Granger, J., Sigman, D. M., Needoba, J. A., and Harrison, P. J.: Coupled nitrogen and oxygen isotope fractionation of nitrate during assimilation by cultures of marine phytoplankton, Limnol. Oceanogr., 49, 1763-1773, 2004.

Granger, J., Sigman, D. M., Lehmann, M. F., and Tortell, P. D.: Nitrogen and oxygen isotope fractionation during dissimilatory nitrate reduction by denitrifying bacteria, Limnol. Oceanogr., 53, 2533-2545, 2008.

Großkopf, T., Mohr, W., Baustian, T., Schunck, H., Gill, D., Kuypers, M. M. M., Lavik, G., Schmitz, R. A., Wallace, D. W. R., and LaRoche, J.: Doubling of marine dinitrogen-fixation rates based on direct measurements, Nature, 488, 361-364, 2012.

Gruber, N.: The dynamics of the marine nitrogen cycle and its influence on atmospheric $\mathrm{CO}_{2}$ variations, in: The Ocean Carbon Cycle and Climate, edited by: Follows, M. and Oguz, T., Kluwer Academic, Dordrecht, the Netherlands, 97-148, 2004.

Gruber, N.: The marine nitrogen cycle: Overview of distributions and processes, in Nitrogen in the Marine Environment, 2nd Edn., edited by: Capone, D. G., Bronk, D. A., Mulholland, M. R., and Carpenter, E. J., Elsevier, Amsterdam, 1-50, 2008.

Hamersley, M. R., Lavik, G, Woebken, D., Rattray, J. E., Lam, P., Hopmans, E. C., Damsté, J. S. S., Krüger, S., Graco, M., Gutiérrez, D., and Kuypers, M. M. M.: Anaerobic ammonium oxidation in the Peruvian oxygen minimum zone, Limnol. Oceanogr., 52, 923-933, 2007.

Kalvelage, T., Jensen, M. M., Contreras, S., Revsbech, N. P., Lam, P., Günter, M., LaRoche, J., Lavik, G., and Kuypers, M. M. M.: Oxygen sensitivity of anammox and coupled N-cycle processes in oxygen minimum zones, Plos ONE, 6, e29299, doi:10.1371/journal.pone.0029299, 2011.

Kalvelage, T., Lavik, G., Lam, P., Contreras, S., Arteaga, L., Loscher, C. R., Oschlies, A., Paulmier, A., Stramma, L., and Kuypers, M. M. M.: Nitrogen Cycling Driven by Organic Matter Export in the South Pacific Oxygen Minimum Zone, Nat. Geosci., 6, 228-234, 2013.

Kritee K., Sigman, D. M., Granger, J., Ward, B. B., Jayakumar, A., and Deutsch, C.: Reduced isotope fractionation by denitrification under conditions relevant to the ocean, Geochim. Cosmochim. Ac., 92, 243-259, 2012.

Kuypers M. M., Lavik, G., Woebken, D., Schmid, M., Fuchs, B. M., Amann, R., Jørgensen, B. B., and Jetten, M. S. M.: Massive nitrogen loss from the Benguela upwelling system through anaerobic ammonium oxidation, P. Natl. Acad. Sci. USA, 102, 6478-6483, 2005.

Kuypers, M. M. M., Sliekers, A. O., Lavik, G., Schmid, M., Jørgensen, B. B., Kuenen, J. G., Sinninghe Damsté, J. S., Strous,
M., and Jetten, M. S. M.: Anaerobic ammonium oxidation by anammox bacteria in the Black Sea, Nature, 422, 608-611, 2003.

Lam, P. and Kuypers, M. M. M.: Microbial nitrogen cycling processes in oxygen minimum zones, Annual Review of Marine Science, 3, 317-345, 2011.

Lam, P., Lavik, G., Jensen, M. M., van de Vossenberg, J., Schmid, M., Woebken, D., Gutiérrez, D., Amann, R., Jetten, M. S. M., and Kuypers, M. M. M.: Revising the Nitrogen Cycle in the Peruvian Oxygen Minimum Zone, P. Natl. Acad. Sci. USA, 106, 47524757, 2009.

Lam, P., Jensen, M. M., Kock, A., Lettmann, K. A., Plancherel, Y., Lavik, G., Bange, H. W., and Kuypers, M. M. M.: Origin and fate of the secondary nitrite maximum in the Arabian Sea, Biogeosciences, 8, 1565-1577, doi:10.5194/bg-8-1565-2011, 2011.

Lehmann, M. F., Sigman, D. M., McCorkle, D. C., Granger, J., Hoffmann, S., Cane, G., and Brunelle, B. G.: The Distribution of Nitrate ${ }^{15} \mathrm{~N} /{ }^{14} \mathrm{~N}$ in Marine Sediments and the Impact of Benthic Nitrogen Loss on the Isotopic Composition of Oceanic Nitrate, Geochim. Cosmochim. Ac., 71, 5384-5404, 2007.

Lipschultz, F., Wofsy, S. C., Ward, B. B., Codispoti, L. A., Friedrich, G., and Elkins, J. W.: Bacterial transformations of inorganic nitrogen in the oxygen-deficient waters of the eastern tropical South Pacific Ocean, Deep-Sea Res., 37, 1513-1541, 1990.

Liu, K. K.: Geochemistry of inorganic nitrogen compounds in two marine environments: The Santa Barbara Basin and the ocean off of Peru, PhD thesis, University of California, Los Angeles, 1979.

Lomas, M. W. and Lipschultz, F.: Forming the primary nitrite maximum: Nitrifiers or phytoplankton?, Limnol. Oceanogr., 51, 2453-2467, 2006.

Mariotti, A., Germon, J. C., Hubert, P., Kaiser, P., Letolle, R., Tardieux, A., and Tardieux, P.: Experimental determination of nitrogen kinetic isotope fractionation: Some principles; illustration for the denitrification and nitrification processes, Plant Soil, 62, 413-430, 1981.

McIlvin, M. R. and Altabet, M. A.: Chemical conversion of nitrate and nitrite to nitrous oxide for nitrogen and oxygen isotopic analysis in freshwater and seawater, Anal. Chem., 77, 5589-5595, 2005.

Noffke, A., Hensen, C., Sommer, S., Scholz, F., Bohlen, L., Mosch, T., Graco, M., and Wallman, K.: Benthic iron and phosphorus fluxes across the Peruvian oxygen minimum zone, Limnol. Oceanogr., 57, 851-867, 2012.

Penven, P., Echevin, V., Pasapera, J., Colas, F., and Tam, J.: Average circulation, seasonal cycle and mesoscale dynamics in the Peru Current System: a modelling approach, J. Geophys. Res., 110, C1002110, doi:10.1029/2005JC002945, 2005.

Richards, F. A., and Benson, B. B.: Nitrogen/argon and nitrogen isotope ratios in two anaerobic environments, the Cariaco Trench in the Caribbean Sea and Dramsfjord, Norway, Deep-Sea Res., 7, 254-264, 1961.

Ryabenko, E., Kock, A., Bange, H. W., Altabet, M. A., and Wallace, D. W. R.: Contrasting biogeochemistry of nitrogen in the Atlantic and Pacific Oxygen Minimum Zones, Biogeosciences, 9, 203 215, doi:10.5194/bg-9-203-2012, 2012.

Sigman, D. M., Casciotti, K. L., Andreani, M., Barford, C., Galanter, M., and Bohlke, J. K.: A Bacterial Method for the Nitrogen Isotopic Analysis of Nitrate in Seawater and Freshwater, Anal. Chem., 73, 4145-4153, 2001. 
Sigman, D. M., Robinson, R., Knapp, A. N., Van Geen, A., McCorkle, D. C., Brandes, J. A., and Thunell, R. C.: Distinguishing between water column and sedimentary denitrification in the Santa Barbara Basin using the stable isotopes of nitrate. Geochem. Geophy. Geosy., 4, 1040, doi:10.1029/2002GC000384, 2003.

Sigman, D. M., Granger, J., DiFiore, P. J., Lehmann, M. M., Ho, R., Cane, G., and Van Geen, A.: Coupled nitrogen and oxygen isotope measurements of nitrate along the eastern North Pacific margin, Global Biogeochem. Cy., 19, GB4022, doi:10.1029/2005GB002458, 2005.

Stramma, L., Bange, H. W., Czeschel, R., Lorenzo, A., and Frank, M.: On the role of mesoscale eddies for the biological productivity and biogeochemistry in the eastern tropical Pacific Ocean off Peru, Biogeosciences, 10, 7293-7306, doi:10.5194/bg-10-72932013, 2013.

Strous, M., Pelletier, E., Mangenot, S., Rattei, T., Lehner, A., Taylor, M. W., and Horn, M.: Deciphering the Evolution and Metabolism of an Anammox Bacterium from a Community Genome, Nature, 440, 790-794, 2006.
Ulloa, O., Canfield, D. E., DeLong, E. F., Letelier, R. M., and Stewart, F. J.: Microbial oceanography of anoxic oxygen minimum zones, P. Natl. Acad. Sci. USA, 109, 15996-16003, 2012.

Voss, M., Dippner, J. W., and Montoya, J. P.: Nitrogen Isotope Patterns in the Oxygen-Deficient Waters of the Eastern Tropical North Pacific Ocean, Deep-Sea Res. Pt. I, 48, 1905-1921, 2001.

Wada, E. and Hattori, A.: Nitrogen isotope effects in the assimilation of inorganic compounds by marine diatoms, Geomicrobiol. J., 1, 85-101, 1978.

Ward, B. B., Devol, A. H., Rich, J. J., Chang, B. X., Bulow, S. E., Naik, H., Pratihary, A., and Jayakumar, A.: Denitrification as the Dominant Nitrogen Loss Process in the Arabian Sea, Nature, 461, 78-81, 2009. 